This manuscript is a preprint and has not undergone peer-review. Subsequent versions of this manuscript may have different content. If accepted, the final version of this manuscript will be available via the 'Peer-reviewed Publication $D O /$ link on the right-hand side of this webpage. Please feel free to contact any of the authors directly or to comment on the manuscript using hypothes.is (https://web.hypothes.is/). We welcome feedback! 


\title{
The role of mass-transport complexes (MTCs) in the initiation and
} evolution of submarine canyons

\author{
Nan $\mathrm{Wu}^{1^{*}}$, Harya D. Nugraha ${ }^{2}$, Guangfa Zhong ${ }^{1}$, Michael J. Steventon ${ }^{3}$ \\ ${ }^{1}$ State Key Laboratory of Marine Geology, Tongji University, Shanghai 200092, China \\ ${ }^{2}$ Center for Sustainable Geoscience, Universitas Pertamina, Jakarta, 12220, Indonesia \\ ${ }^{3}$ Shell Research, Shell Centre, London, SE1 7NA, UK. \\ *Email: nanwu@tongji.edu.cn
}

\section{Abstract}

The offshore area of the Otway Basin, located within the SE continental margin of Australia, is dominated by a multibranched canyon system where submarine mass-transport complexes (MTCs) are widely distributed. We integrate high-resolution multi-beam bathymetric and seismic reflection data to investigate the importance of regionally distributed MTCs in dictating the evolution of canyon systems. We interpret three regionally distributed MTCs that fail retrogressively and affect almost $70 \%$ of the study area. Within the MTCs, we observed seven canyons that initiated from the continental shelf edge and extended to the abyssal plain. Although these canyons share common regional tectonics and oceanography, the scales, morphology, and distribution are distinctly different. This is devoted to the presence of failure-related scarps (i.e. headwall and sidewall scarps) that control the initiation and formation of the canyons. The retrogressive failure mechanisms of MTCs have created a series of the headwall and lateral scarps on the continental shelf and slope regions. In the continental shelf, where terrestrial input (i.e. fluvial systems) is absent, the origin of the canyons is related to the local failure events and the contour current activities occurring near the pre-existing, massive headwall scarps (c. $120 \mathrm{~m}$ high, $3 \mathrm{~km}$ long). The occurrence of these local failures has provided the necessary sediment input for subsequent gravity-driven, downslope sediment flows. In the continental slope region, the widespread scarps can capture gravity flows initiated from the continental shelf, developing an area of flow convergence, which greatly widens and deepens the canyon system. The gradual diversion and convergence through MTCs related scarps have facilitated the canyon confluence process, which has fundamentally changed the 
canyoning process. Thus, we conclude that the retrogressive failure mechanism of MTCs has a direct contribution to the initiation, distribution, and evolution of the canyons, especially in areas where fluvial input is missing. Moreover, the retrogressive failure mechanism is responsible for the canyon deepening and confluence process, which can greatly facilitate the delivery of sediment into deep oceans.

\section{Introduction}

Submarine canyons are defined as steep-sided V- or U-shaped valleys that are cutting into the seabed, extending from the continental shelf to the continental slope areas, with numerous tributaries entering from both sides (Shepard et al., 1966; Twichell and Roberts, 1982; Obelcz et al., 2014). Canyons are complex geomorphology features formed by erosion from sediment gravity flows occurring near the continental margins (Shepard, 1972; Canals et al., 2006; Harris and Whiteway, 2011). Canyons are often associated with sand-rich gravity flows and submarine fans are thus considered as modern analogues for deepwater hydrocarbon reservoirs (Stow and Mayall, 2000; Weimer and Slatt, 2004). Mass-transport complexes (MTCs) are gravity-driven shear failure deposits resulting from creep, spread, slide, slump and debris flow processes (Posamentier and Martinsen, 2011; Wu et al., 2021). MTCs can be extremely erosive, thus containing large volumes of sediments, with single deposits covering areas of $>100 \mathrm{~km}^{2}$ and volumes $>10,000 \mathrm{~km}^{3}$ (Frey Martinez et al., 2005; Moscardelli and Wood, 2016; Nugraha et al., 2019). MTCs normally fail retrogressively (i.e. backstepping slope failures), the emplacement of MTCs can leave a series of giant slide scars (c.2-5 km wide) on the continental slope areas (Figure 1a, 1b; i.e. Williams, 2016; Li et al., 2017). Both MTCs and canyons can transfer large amounts of sediments between the continental shelf and abyssal plain environments, they are considered as important sediment transportation conduits in deepwater settings (McAdoo et al., 2000; Popescu et al., 2004; Antobreh and Krastel, 2006; Lee et al., 2007; Urgeles and Camerlenghi, 2013).

Submarine canyons and MTCs have a close relationship in terms of their spatial distribution, triggering mechanisms, and preconditioning factors (Micallef et al., 2012; Watson et al., 2020). The emplacement of MTCs can represent the early phase of submarine canyon initiation, providing early depressions on the continental slopes that extend to the shelf break (Farre et al., 1983). The 
continuous downcutting process associated with canyon development can steepen the gradient of canyon sidewalls, which preconditions the intra-canyon MTCs near the canyon walls (i.e. Farre et al., 1983; Green and Uken, 2008). The intra-canyon MTCs occur retrogressively, increasing the canyon's width (i.e. lateral extension; Pratson and Ryan, 1994) and extending the canyon upslope (i.e. headward incision; Farre et al., 1983; He et al., 2014). Most of the published works have focused on constraining local, coeval, intra-canyon MTCs (senus detached MTCs; Moscardelli and Wood, 2008) with the evolution of the canyons (i.e. Green and Uken, 2008; Gong et al., 2011; He et al., 2014; Su et al., 2020). The relationship between canyons with the regional distributed MTCs (i.e. 100 s to 100,000 s of $\mathrm{km}^{2}$ ) (senus attached MTCs; Moscardelli and Wood, 2008) that typically fails retrogressively, have largely been overlooked. Relatively little is known on how regionally distributed MTCs, especially how their retrogressive failure mechanism can influence the initiation, evolution, and morphology of submarine canyons. Therefore, this study uses a high-resolution (c. $10 \mathrm{~m}$ vertical resolution) 3D seismic reflection dataset, integrated with 2D seismic and multi-beam data to analyse the spatial and temporal relations between canyons and regional distributed MTCs in the Otway Basin, southern Australia (Figure 2a, 2b).

\section{Geological setting}

\subsection{Tectonic}

The Otway Basin is a broadly NW-SE striking offshore non-volcanic, rift basin located along the SE Australian passive margin (Figure 2). The basin was initiated by late Jurassic to early Palaeogene rifting, during the progressive breakup of southern and eastern Gondwana. After experiencing multistage rifting, thermal subsidence and inversion, the south Australian margin ultimately broke with Antarctica at the end of the Cretaceous (approximately 67 Ma; Willcox and Stagg, 1990; Perincek and Cockshell, 1995; Krassay et al., 2004; Totterdell et al., 2014). Although the detailed history of the separation and final breakup between Australia and Antarctica remains partially studied (Gibson et al., 2013; Holford et al., 2014), the formation of a regionally distributed Maastrichtian unconformity has been attributed to the eventual separation of Australia and Antarctica Plates (Figure 3; Krassay et al., 2004; Holford et al., 2014). 
Sedimentary successions in the Otway Basin during Cenozoic has been progressively influenced by marine-related, often calcareous-rich sediments, reflecting an open marine depositional environment (McGowran et al., 2004). The Cenozoic post-rift sedimentation is represented by the Wangerrip Group (late Palaeocene to middle Eocene, mainly siliciclastic rich), the Nirranda Group (middle Eocene to early Oligocene, mainly containing sandstones and marls), the Heytesbury Group (late Oligocene to late Miocene, mainly contains marls and limestones), and the Whalers Bluff Formation (WBF; Pliocene-Recent, mainly contains a mixed siliciclastic-carbonate sediments) (Figure 3a; Dickinson et al., 2002; Krassay et al., 2004; Holford et al., 2014). Our study interval lies in the WBF formation at a time when the study area was in a passive continental margin setting. In the continental slope area, thick, localised sediments deposited in the Pliocene-recent succession represent marine clastic sediments deposited in the submarine canyons (Figure 3b, 3c) (Tassone et al., 2011).

\subsection{Oceanography}

Two shelf break currents dominate the current day ocean circulation in the study area (Duran et al., 2020): (i) the eastward-flowing South Australia Current (SAC) and (ii) the south-eastwardflowing Zeehan Current (ZC) (Figure 2b). The South Australia Current is a eastward flow with high salinity, high velocity $(0.5 \mathrm{~m} / \mathrm{s}$ ), it is flowing down to $300 \mathrm{~m}$ water depth (Duran et al., 2020). The Zeehan Current is fed by the South Australian Current, it is a poleward current with low salinity, and high current velocity $(0.4 \mathrm{~m} / \mathrm{s})$, flowing down to $300 \mathrm{~m}$ water depth (Ridgway, 2007).

As the fluvial activity is limited in the study area (McGowran et al., 2004), the mounded seismic facies (sub-parallel to wavy, low- to high amplitude, internal truncations) in the WBF Formation have a clear indication of the contour current activity (Figure 3b, 3c; i.e. Nugraha et al., 2018). The modern canyons show a clear eastward lateral migration compare to the buried Pliocene canyons in the continental shelf region (Figure 3c). These observations all indicate the overall eastward shelf break parallel currents (SAC and LC) affect the sedimentary processes in the continental shelf region.

\section{Dataset and Methodology}

\subsection{Multibeam Dataset}



morphology and associated canyons and MTCs, especially in areas absent of seismic-reflection data

116 (Figure 4a).

\subsection{Seismic Dataset}

The 3D pre-stack time migrated (PSTM) seismic-reflection data were acquired by Santos in 2002, located in the vicinity of Portland, offshore SE Australia (Figure 2b). The survey covers an area of $c$. $360 \mathrm{~km}^{2}$ with a bin spacing of $25 \mathrm{~m} \times 12.5 \mathrm{~m}$ (inline $\times$ crossline), and a dominant frequency of 50 $\mathrm{Hz}$ at the seabed. We estimate that the spatial resolution of the seismic data, given an average velocity of the near seabed sediment derived from the seismic report $(1824 \mathrm{~m} / \mathrm{s})$, is c. $9 \mathrm{~m}$. The 3D seismic data are zero-phase, and presented in SEG normal polarity with an increase in acoustic impedance expressed as a positive amplitude.

\subsection{Methodology}

The seismic-stratigraphic framework is correlated with Holford et al. (2014) work in the adjacent area. Seismic and multi-beam data are used to map MTC and canyon related features. The key morphometric parameters of the canyons (i.e. canyon width and height) are quantitatively measured and discussed to reveal the sedimentary processes involved in the canyon origin and evolution. In this study, the canyon width is defined as the distance between the canyon shoulders. The canyon height is defined as the depth from the canyon shoulder to the canyon base.

\section{Result}

\subsection{Morphology of the study area}

The study area spans from the continental shelf, to slope, to abyssal plain environment (Figure 4a). The morphology of the study area is characterised as having a narrow (c. $7 \mathrm{~km})$ and steep slope (Figure 4a). The continental shelf area dips from $0.4^{\circ}$ to $1^{\circ}$ with an average water depth of $250 \mathrm{~m}$ (Figure 4a). The continental slope area is characterised by a relatively gentle slope of c. $10^{\circ}$ in the upper section, to a steep slope gradient of c. $30^{\circ}$ near the lower section, with water depths ranging from $600 \mathrm{~m}$ to $1500 \mathrm{~m}$, respectively (Figure 4a). The multi-beam and seismic data reveal several 
canyons initiated from the continental shelf region, spanning the continental slope, and ultimately terminating in the abyssal plain (Figure 4a). The topographic profiles extracted from the multibeam data showed dramatic differences in the across-canyon margin morphology (Figure 4b). The width of canyons increases along with the dip of the slope, with canyons converging at the abyssal plain (Figure 4b, 4c).

\subsection{MTCs and canyons}

Three MTCs (MTC-1, MTC-2, and MTC-3) have been interpreted in the study area (Figure 5a, 5b). Seismic data reveals several distinctive NNW-SSE oriented extensional scarps, and NE-SW oriented lateral extensional scarps near the shelf-edge, and within the slope and abyssal plain (Figure 5b). The arcuate NNW-SSE dipping extensional scarps are interpreted as MTC headwall scarps that mark the updip part of an MTC, where extensional deformation dominates (Figure 5b; i.e. Bull et al., 2009). The NE-SW dipping lateral scarps are interpreted as MTCs lateral margins that separate deformed sediments (MTCs) from the undeformed seabed (Figure 5b; i.e. Frey Martinez et al., 2005; Bull et al., 2009). Based on the orientation of headwall scarps and lateral margins, the MTCs are predominately transported subparallel to the dip direction of the slope. Seven major canyons (canyon 1-7) spanning from continental shelf to abyssal plain are observed within the MTC influenced area (Figure 5a, 5b). They are oriented NNW-SSW on the continental slope, sub-parallel to the dip direction of the slope. Canyon-1-3 and Canyon-7 are initiated from shelf edge headwall scarps with clear landward incision features, while Canyon-4-6 are restricted in the continental slope (Figure 5b). As the study area is disconnected to the modern fluvial system (Leach and Wallace, 2001), which indicates a limited sediment input at or near the canyon heads. The canyons are thus relatively sediment starved as compared to canyons connected with direct fluvial input (e.g. the Type 1 canyons from Jobe et al., 2011).

\subsection{MTC-1}

In MTC-1, multiple headwall scarps (HS-1 to HS-5) and their associated lateral margins are observed from the map view and the correlated seismic sections (Figure 6a, Figure 7a). Headwall scarps are recognised as upward concaved lineation with scallop-shaped geometry (Figure 6b). In the seismic dip section, the headwalls are nested in a terraced style, showing a truncated reflector that cuts through upslope sediments (Figure 7a). The heights and angles of the scarps vary considerably throughout MTC-1, with the highest (c. $170 \mathrm{~m}$ ) and steepest (c. $\left.40^{\circ}\right) \mathrm{HS}-5$ occurring in the upper 
171 and gentler than HS-5, with similar morphology and distributed in the central part of the MTC-1

172 (Figure 7b-d). The middle part of MTC-1 has a hummocky seabed expression in map view and 173 contains chaotic and blocky seismic facies in seismic section (Figure 6b, 7a). A clear basal shear 174 surface with a gentle gradient (c. $3^{\circ}$ ) that separates the underlying layered seismic facies from the 175 overlying chaotic seismic facies has been observed below the HS-4 and HS-1 (Figure 7a). The 176 chaotic and blocky facies accumulated downdip to the HS-4 and HS-1, showing a wedge-shaped 177 geometry in seismic section (Figure 7a, 7c) and a fan shaped geometry in plain view (Figure 6b).

178 The presence of the backstepping stair shape geometry, the relative flat basal shear surface, and 179 the deposition of chaotic seismic facies near the distal part of HS-4 and HS-1, suggests that the 180 initial failure started at the lowermost part of MTC-1 and propagated retrogressively towards the upper slope area. We thus interpret multiple headwall scarps (HS-1 - HS-5) resulting from multiple retrogressive failure events, such as recorded in the Storegga slide and other MTCs (i.e. Bryn et al., 2005; Sawyer et al., 2009; Badhani et al., 2020). The occurrence of retrogressive failure has resulted in linear to sinuous depression features in plan-view (Figure 6b), and small-scale faults or fractures in seismic cross-section (see headwall scarps in Figure 7b-d).

\subsection{Canyons in MTC-1} In the upper section of MTC-1, the canyon system comprises three tributaries (Canyon-1 to Canyon-

188 3; Figure 6b, 7b). They are originally initiated from the scarps near the shelf edge (Figure 5). 189 Canyon-1 and -2 are developed in the NE part of MTC-1, while Canyon-3 is in the NW part (Figure 6b). Canyon 1-3 have more pronounced seabed erosion than MTC-1. Near the HS-5, clear seabed incision and truncations can be observed in the seismic sections that image the canyons (Figure 7b). Canyons 1-3 have a linear geometry in map view. The cross-sectional geometry of canyons is generally U-shaped, with a gently sloping base surface (c. $1^{\circ}$ ) and steep canyon sidewalls (c. $60^{\circ}$ ) (Figure 7b, 7c). Canyons 1-3 trend downslope from the continental shelf towards the HS-5 of MTC1 and converge near the HS-3 (the confluence point; Figure 6b), and ultimately converging into a broad canyon after passing through HS-2, at a water depth 1522 m to 1595 m (Figure 6b, 7d).

197 Numerous crescentic bedforms and axial incisions are observed along the axis of Canyon 1-3 198 (Figure 6b). In the pre-confluence region (abyssal plain area), the Canyons 1-3 ranges from c. 100 $199 \mathrm{~m}$ to c. $670 \mathrm{~m}$ wide and c. $20 \mathrm{~m}$ to $134 \mathrm{~m}$ high (Figure 7e, 7f). In the post-confluence area, the width 
increases from c. $370 \mathrm{~m}$ to c. $1140 \mathrm{~m}$, which is $2-3$ times wider than that of in the pre-confluence region (Figure 7e). The canyon height increases from c. $90 \mathrm{~m}$ to c. $140 \mathrm{~m}$ in the post-confluence area, slightly larger than the canyons in the pre-confluence area (Figure 7f).

This stratigraphic relationship between canyons and MTC-1 indicate that the deposition of the MTC-1 occurred prior to the initiation of canyons. The crescentic bedforms are possibly associated with supercritical currents (i.e. Zhong et al., 2015), suggesting gravity flows are still being initiated, and canyons are remaining active as a sediment pathway today. Quantitative analyses of the canyons indicate a strong correlation exists between the canyon width/height with distance along the different MTC-1 headwall scarps. The sharp increase of the canyon's width and depth after the confluence point (near the HS-3) indicate headwall scarps has played a key role in dictating the canyon morphology and erosivity. We thus indicate the topography within MTC-1 was established as a function of topographic confinement imposed by the backstep headwall scarps. The existence of the headwall scarps can facilitate the canyon widening and deepening process.

\subsection{MTC-2 and MTC-3}

MTC-2 was deposited at the west of the MTC-1 (Figure 5b). MTC-2 has an E-dipping main headwall scarp located in the lower slope setting, a south-dipping western lateral margin, and its eastern lateral margin has been eroded by the MTC-1 (Figure 8a, 8b). MTC-2 contains four internal headwall scarps (HS-1 to HS-4; Figure 8b) and associated lateral margins. Along the proximal part of the western lateral margin, the sidewall displays up to at least three levels of local retrogressive failures that make the west lateral margin complexed (Figure 8b). The cross-cutting relationship between MTC-1 and MTC-2 reveals MTC-2 occurred after the MTC-1. Similar to MTC-1, the multi-headwall scarps are the result of the retrogressive failure events associated with the emplacement of MTC2. MTC-3 was deposited in the west of the study area (Figure 5b). Distinctive NNW-ESE dipping headwall scarps can be only identified near the upper boundary of the MTC-3 (Figure 8b). Scarps in MTC-3 are significantly less than those in the MTC-1 and MTC-2 (Figure 8b).

\subsection{Canyons in MTC-2} Two canyons (Canyon-4 and Canyon-5) that initiated from the lower slope setting, incised across MTC-2, with a little (c. $<50 \mathrm{~m}$ height) bathymetric expression in plain view (Figure $8 \mathrm{a}, 8 \mathrm{~b}$ ). The morphology of Canyon-4 is only visible in map view near the lower slope, and it loses surface expression at the location of HS-4 (Figure 8b). Upslope from the Canyon-5 head, two channels are 

scarps within MTC-2, being initially WNW-SE strike at the location of HS-4 and HS-3, shifting to SE at the site of HS-2, and shifting again to an abrupt SW bend at HS-1 (Figure 8b). After passing through HS-1, Canyon-5 is oriented southward (Figure 8b). Seismic profiles of canyon-5 reveal a Ushaped erosional feature, and the cross-sectional morphology keeps constant along the canyon-5's pathway (Figure 9a-c). The width and height of canyon-5 have a constant variation compared to Canyon-1 (Figure 9d). The upper reach of canyon-5 has a deeper incision and width that can reach $76 \mathrm{~m}$ and $565 \mathrm{~m}$, respectively. In the abyssal plain, the width of canyon- 5 decreases from $565 \mathrm{~m}$ to c. $370 \mathrm{~m}$, and increases to $750 \mathrm{~m}$ after passing through HS-3 (Figure 9d). The width of Canyon-5 drops sharply to $343 \mathrm{~m}$ after passing through HS-1. The height of the Canyon-5 constantly decreases from c. 58 m near the HS-4 to c. 44 m near the HS-1 (Figure 9d). In summary, from the HS-4 to HS-1, the Canyon- 5 becomes narrower and less incised. Limited distribution of Canyon-4 indicates that the canyon incision has been isolated to the lower 243 slope. The rapid shifting of Canyon-5 pathway indicates the presence of headwall scarps can 244 influence and divert the canyon transport direction. Canyon-5 has a clear backstep (landward) incision and relates to a shelf edge headwall by channels, and this might suggest Canyon- 5 is still active during the Holocene. We suggest with the headward incision associated with canyon-5, once the canyon head connects to shelf-edge headwall scarps, it will grow into a 'mature' stage akin to the canyons in MTC-1.

\subsection{Canyons in MTC-3}

250 Two canyons (Canyon-6 and Canyon-7) are observed in MTC-3. The morphology of Canyon-6 is only visible close to the lower slope (Figure 8b, Figure 10b). Farther downslope, the Canyon-6 lose its morphology in map view, and there is no visible canyon form in the seismic section as well (Figure 10c). The canyon-7 has a tripartite, concave head that cut c.7 km landward into the shelf (Figure 8b). The cross-sectional geometry of canyon-7 shows a clear V-shaped incision. However, this Vshaped downcutting geometry is only constrained in the lower slope region (Figure 10a, 10b). The width and the height of canyon-7 are constantly low in the abyssal plain, ranging from c. $120 \mathrm{~m}$ to $175 \mathrm{~m}$ and c. $20 \mathrm{~m}$ to $50 \mathrm{~m}$, respectively (Figure $10 \mathrm{~d}$ ). which might indicate that the flow contributes to the formation of canyons that have been largely 
displaced due to the absence of headwall scarps. Moreover, due to the absence of the scarps,

261 Canyon-6 and Canyon-7 show a low sinuosity and a subparallel pathway. No major canyon diverting,

262 nor converging has been observed in the MTC-3 region (Figure 8b).

\section{5. Discussion}

\subsection{Origin of the canyons}

The study area has a low sediment supply and is characterised by disconnection to modern fluvial systems (Leach and Wallace, 2001). Canyons in the study area are thus sediment starved compared to canyons connected to fluvial input in other areas. Similar canyons that being isolated from major river input, with linear morphology of low sinuosity, have been documented from other margins (termed as Type II canyon; sensu Jobe et al., 2011). The initiation of the type II canyons are connected to the local failures near the continental margins or continental slopes, which is independent of sediment input (i.e. river feed) and sea-level fluctuation (i.e. Normandeau et al., 2014). Other triggers, such as the constructions and modification by turbidity and bottom currents near the canyon heads, have also been suggested to the initiation of the type II canyons (i.e. Jobe et al., 2011).

In this study, the morphology of the canyon heads is strictly constrained within the headwall scarps near the shelf edge (Figure 11a, 11b). The spatial relation between the shelf-edge headwall scarps and canyon heads suggests the initiation of canyons are closely related to these pre-existing, steep shelf-edge headwall scarps. Moreover, as the bottom current is active near the shelf-edge area, the movement of the bottom current along the topographically low scarps may induce local turbulence and produce down canyon sediment transportation (i.e. Fenner et al., 1971; Warratz et al., 2019). Thus, we suggest that the canyon systems in the study area are initiated by a combination of multistage retrogressive failure events and contour current activity near the pre-existing headwall scarps (Figure 11c). Although the study area lacks river-sourced sediments, canyon heads can capture sediment from local failure events associated with gravity flows that erode the seabed and form canyons downslope (Figure 11d) (see also similar process from Atlantic canyons; Twichell and Roberts, 1982). Other factors, such as hurricanes, typhoons and tidal currents occurring in the continental shelf area, may also contribute to the canyon initiation (Shepard et al., 1974; Sequeiros 
et al., 2019). The emplacement of the hurricanes and typhoons can trigger waves and currents, thus resuspending and carrying sediment. These processes will directly play a role in initiating the turbidity currents, which bring the sediments into the canyon heads and enhance the canyoning process (Sequeiros et al., 2019). Tidal currents can act as an efficient force for reworking and carrying sediments in submarine settings (Shepard et al., 1974). Tidal currents can thus transport sediments into the canyon heads area, especially at places where river input is missing.

\subsection{Role of retrogressive failure mechanism on canyon evolution}

The headwall scarp of MTCs play an essential role in capturing turbidity currents and facilitating turbidity channelization in submarine settings, as proved by examples from previous seismic- and outcrop-based studies (Loncke et al., 2009; Alves and Cartwright, 2010; Ito, 2013; Qin et al., 2017; Li et al., 2020). The three MTCs presented in this study have indicated the spatial variation of canyon morphology is linked with the MTCs morphometric characteristics. Here, we attempt to define the possible mechanical influences of MTCs imposed on the canyon evolution in the 301 following section.

The retrogressive failure events associated with MTC-1 have left a pronounced negative seafloor space that greatly changed the slope morphology and created a series of localised seafloor 'ponding' accommodations along the pathway of submarine canyon systems. The gravity-driven downslope processes are sensitive to the slope gradient variations, preferentially deposited where the gradient varies the most (Kneller et al., 2016). The varied hierarchies of headwall scarps can therefore trap or divert subsequent turbidity currents and facilitate canyon systems' incision and development. Though the headwall scarps within MTC-2 does not widen nor deepen canyons that are transported through, they do play an essential role in changing the canyon direction. Compared to MTC-1 and MTC-2, MTC-3 has provided a good opposite example. Within MTC-3, due to the lack of internal headwall scarps, thus lack of ability to trap or capture the turbidity currents flow through. Even the Canyon- 6 has connected to the shelf-edge headwall scarps, the scale of the canyon is still small compared to canyons in the other two MTCs. Therefore, we indicate the retrogressive failure mechanism of MTCs is responsible for canyon deepening and confluence process, which can greatly influence the morphology of the canyons.

\subsection{Other factors that may influence the evolution of the canyon}

The evolution of submarine canyons can also be influenced by many other geological factors, 
including (i) regional tectonics (i.e. regionally distributed faults), which influence the sediments strength, thus the susceptibility to erosion during the formation of canyons (Covault et al., 2007); (ii) the sea-level variation, which can boost sediment input to canyon heads (Vail, 1977; Posamentier et al., 1991); (iii) downslope and along-slope depositional processes (i.e. gravity flows and contourite currents), which erode seafloor and enlarge the scale of submarine canyons (Pratson and Coakley, 1996; He et al., 2014; Miramontes et al., 2020). In this study, tectonics is unlikely to be of significance for canyon development due to the relatively stable nature of the southern Australian continental margin. Recent studies revealed that the canyon process does not necessarily depend on the sea-level rise and fall, as well-developed canyon systems have been identified during the sea-level rise in many submarine settings (i.e. Xu et al., 2010; Paull et al., 2013; Normandeau et al., 2015). In the study area, the modern canyons are contiguous with Pliocene canyon systems, showing similar geometry and slightly eastward migrated distribution pattern. The similarities between buried Pliocene and modern canyons indicate that the location and distribution of modern canyons are an extension of the infilled Pliocene canyon systems. The overall eastward canyon lateral migration during Pliocene-Recent is interpreted as related to an eastward shelf break parallel paleocurrent (i.e. SAC or LC), which is still active near current-day shelf-edge (Godfrey et al., 1986). Moreover, our study suggests that the types of the underlying deposits can also influence the morphology evolution of the canyons. For example, Canyon-1 to Canyon-3 deposit above the slope background deposits (Figure 7b), while Canyon-6 deposits above a buried MTC (Figure 10c). The quantitative analyses reveal that the Canyon-1 to Canyon-3 (immediately above background deposits) are tentatively larger than that of the Canyon-6 (immediately above buried MTCs). This is interpreted as buried MTCs, which are normally more consolidated than undeformed background slope deposits (i.e. Shipp, 2004; Sawyer, 2007; Wu et al., 2021). Thus, the erosivity and scale of the Canyon-6 are smaller than other canyons. 5.4 Canyon evolution model

We attempt to build an updated model of canyon formation based on the models by Jobe et al.

344 (2011) and Pratson and Coakley (1996), emphasising the role of headwall scarps associated with 345 the regional distributed MTCs. Our model consists of three phases, MTC deposition, canyon initiation, and canyon transition. 
Earthquakes (i.e. Bornhold and Prior, 1989), sediment overloading generated overpressure (i.e.

349 Dugan and Flemings, 2000), or tectonic oversteepening (i.e. Moscardelli et al., 2006) may have

350 triggered the initial failure in the lower slope setting. The initial failure creates an open scarp, that

351 leaves the sediments in the up-dip part unstable. As the gravitational strain accumulates, the

352 sediments that near the initial scarp weaken. A new extensional failure (the second scarp) will

353 occur behind the initial scarp once the sediments become weaker than the along slope gravity-

354 induced stress. The failure process will continue up-dip until the final balance between the shear

355 strength of the slope sediments and the shear stress of the gravitational forces (Sawyer et al., 2009).

356 This retrogressive failure mechanism has left a series of headwall scarps and lateral scarps on the

357 continental shelf and slope settings. The scarp-rich environment represents the initial phase of

358 canyon initiation (Figure 12a).

359 Phase 2: the initial stage of the canyon system

360 The failed sediments near the headwall scarps at the shelf edge have led to triangular-shaped 361 canyon heads, that incised into the landward direction (Figure 12b). The failed sediments could 362 excavate the pre-existing headwall scarps and contribute to the initial sediment influx for canyon 363 initiation (see the similar process from Pratson and Coakley, 1996; Puga-Bernabéu et al., 2011).

364 Once the canyon has been initiated, sediments collapse from the canyon sidewalls (canyon flank 365 failures) forms downslope flowing turbidity currents, facilitating the canyoning process. The failure 366 events associated with headwall scarp and canyon sidewalls permitted the delivery of enough 367 material to enable canyon formation and downward incision. Thus, the initiation mechanism for 368 canyons is the failure of sediments at the headwall scarps of the continental shelf and the 369 downslope eroding flows (Figure 12b) (see also similar process documented by: Pratson and Ryan, 370 1994; Pratson and Coakley, 1996; Armitage et al., 2010). Prevailing along-coast, eastward currents 371 may also create local turbulence near the shelf-edge headwall scarps, which further facilitate the 372 formation of flows that carry sediments into the canyon heads.

\section{Phase 3: transitional stage}

374 With the continuous failure near the shelf-edge headwall scarps, the canyon heads gradually 375 establish into triangular or dendritic shapes. These triangular or dendritic shape structures 376 facilitate canyon head capture and funnel larger volumes of sediments into the canyon, and the 377 canyoning process becomes self-propagating (Figure 12b). The failed sediments near the headwall 

catchment areas for the canyon evolution. Downward sediment gravity flow generated by the failed sediments can contribute significantly to the ongoing canyon excavation and downslope propagation (Popescu et al., 2004; Baztan et al., 2005). The presence of the headwall scarps on the slope settings provided further acceleration and canyon tributary convergence. The canyons are thus progressively propagating to the far side of the lower slope and abyssal plain.

\subsection{Implication}

Many studies have shown how submarine MTCs rugose top surface can capture/reroute subsequent sediment pathways based on seismic data (Loncke et al., 2009; Ortiz-Karpf et al., 2015; Qin et al., 2017) and outcrops (Armitage et al., 2009; Jackson and Johnson, 2009; Kneller et al., 2016). These studies are examples of MTCs locates near the shelf edge where the sediment supply is high. The rugose top surfaces developed along the upper surface of MTCs is caused by the presence of the internal rafted blocks. The rugose topography can be healed quickly by subsequent sand-rich turbidity currents or separate failures. Thus, MTCs have a direct influence in the location and distribution of reservoirs and important implications for hydrocarbon exploration. Conversely, our study documents MTCs in low sediment supply margins where large-scale sediment bypass is missing. We showed strong evidence that the emplace of MTCs has played a key role in influencing the morphology evolution of canyon systems. We develop a generic model of the MTCs headwall scarps, as a function of triggering and influencing the morphological evolution of canyons, thus controlling the sediment bypass from the shelf edge to lower slope and further abyssal plain. We indicate the retrogressive failure mechanism can facilitate long-distance sediment transportation within canyon systems, and it may be a common and important process in a submarine setting where modern river systems are absent.

\section{Conclusion}

This study uses multi-beam bathymetry and seismic reflection data to document how the retrogressive failure mechanism of MTCs and related headwall scarps have influenced the origin, geometry, and distribution of canyons in a sediment starved submarine setting. In summary: (i) the emplacement of MTCs have left multi-scaled headwall scarps and lateral margins on the 
continental margin and slope area, (ii) the local failures developed associated headwall scarps near the continental shelf-edge have provided the initial sediment supply for canyon evolution, (iii) the headwall scarps which developed in the slope setting may act as the preferential pathways for sediment gravity flows, and facilitate canyon development, (iv) we thus indicate that retrogressive failure mechanism can facilitate long-distance sediment transportation within canyon systems in starved submarine settings.

\section{Acknowledgements}

The authors would like to thank Geoscience Australia for providing the seismic reflection and multibeam data used in this study. The first and the third author thanks the State Key Laboratory of Marine Geology for its financial support.

\section{Figure Captions}

Figure 1. (a) Model showing the time evolution of retrogressively failed MTCs, modified from Sawyer et al. (2009). (b) Schematic sketch showing the different stages of a retrogressive failure, modified from Locat et al. (2011).

Figure 2. (a) Regional map of the study area. (b) Zoom in map of the study area showing the location of the city Portland and the Otway Basin. The white lines represent 2D seismic reflection data, and the red polygon represents the location of the 3D seismic reflection dataset. Shaded relief GEBCO_2014 bathymetry map downloaded from https://www.ngdc.noaa.gov/maps/autogrid/. Abbreviations for the Otway Basin are as follows: SAC: South Australia Current, ZC: Zeehan Current. Figure 3. (a) Stratigraphic and basin event chart for the Otway Basin (modified after Krassay et al., 2004), including lithology interpretation and major tectonic events. The Horizon $\mathrm{H} 1$ has been correlated to the intra-Maastrichtian unconformity surface from Holford et al. (2014). The Horizon $\mathrm{H} 2$ is corelated to the base of the WBF. (b) Regional along slope seismic section showing the overall tectonic of the study area. See location from Figure 2b. (c) Regional seismic section that perpendicular to the slope, showing the four key seismic sections (H1 to seabed) and canyon bearing intervals. See location from Figure $2 \mathrm{~b}$. 
Figure 4. (a) Multi-beam bathymetry map of the study area illustrating the seafloor morphology. The red polygon stands for the location of 3D seismic data. The location of this figure is marked by the black dashed line in Figure 2b. (b) Bathymetric profile crossing the abbysal plain, showing the cross-sectional morphology of two canyon systems. (c) Bathymetric profile revealing the combination of the two canyon systems. See location in Figure 4a.

Figure 5. (a) Contoured seafloor map of the study area extracted from the 3D seismic reflection data. (b) Schematic representation of seafloor geomorphologic interpreted from Figure 5a. See the location of this figure from Figure 2.

Figure 6. (a) Zoomed in contoured seafloor map showing the region of MTC-1. (b) Interpreted map of Figure 6a, showing the major headwall scarps in MTC-1 and the location of Canyon-1, Canyon-2, and Canyon-3.

Figure 7. (a) The NW-S oriented seismic section of MTC-1 shows backstep shaped headwall scarps and MTC-1's basal shear surface. (b) Seismic cross-section cutting through HS-5 and HS-4, showing the cross-section of the upper part of the Canyon-1, Canyon-2, and Canyon-3. (c) Seismic crosssection cutting through HS-3, showing the cross-section of the proximal part of the Canyon-1, Canyon-2, and Canyon-3. (d) Seismic cross-section cutting through HS-2 and HS-1, showing the cross-section of the post confluence part of the canyon system in MTC-1. See location in Figure 6b. (e) Width profile of the canyon system in MTC-1. (f) Height profile of the canyon system in MTC-1. Figure 8. (a) Zoomed in contoured seafloor map showing the location of MTC-2 and MTC-3. B) Interpreted map of Figure 8a, showing the headwall scarps in MTC-2 and MTC-3, and the location of Canyon-4, Canyon-5, Canyon-6, and Canyon-7.

Figure 9. (a) Seismic cross-section cutting through HS-5 and HS-4 of MTC-2, showing the upper part of the Canyon-4 and Canyon-5. (b) Seismic cross-section cutting through HS-2 of MTC-2, showing the proximal part of the Canyon-5. (c) Seismic cross-section cutting through MTC-2, showing the distal part of Canyon-5. See location in Figure 8b. (d) Width and height profile of the Canyon-5 in MTC-2.

Figure 10. (a) Seismic cross-section cutting through the headwall of MTC-3, showing the upper part 459 of the Canyon-7. (b) Seismic cross-section showing the proximal part of the Canyon- 6 and Canyon460 7. (c) Seismic cross-section showing the distal part of Canyon-6 and Canyon-7. See location in Figure 8b. (d) Width and height profile of the Canyon-7 in MTC-3. 
462 Figure 11. (a) 3D view of seafloor morphology showing the head of Canyon-5 and Canyon-7, and 463 the headwall scarps occurring on the shelf-edge. See location in Figure 5a. (b) 3D view of seafloor 464 morphology showing the head of Canyon-3, and the headwall scarps occurring on the shelf-edge. 465 See location in Figure 6a. (c) Sketch of 2D view of seafloor morphology showing the headwall 466 collapse and the initial stage of canyon evolution on shelf-edge. (d) Sketch of 2D view of seafloor 467 morphology showing the formation of the canyons.

468 Figure 12. Schematic figure showing the evolution model of the canyon system in the study area. 469 (a) Schematic figure showing that the occurrence of slope attached MTCs and associated headwall 470 scarps. (b) Schematic figure showing that canyons were captured, converged and re-directed by 471 the pre-existing headwall scarps. 
Alves, T.M., Cartwright, J.A., 2010. The effect of mass-transport deposits on the younger slope morphology, offshore Brazil. Marine and Petroleum Geology 27, 2027-2036.

Antobreh, A.A., Krastel, S., 2006. Morphology, seismic characteristics and development of Cap Timiris Canyon, offshore Mauritania: a newly discovered canyon preserved-off a major arid climatic region. Marine and Petroleum Geology 23, 37-59.

Armitage, D.A., Piper, D.J., Mcgee, D.T., Morris, W.R., 2010. Turbidite deposition on the glacially influenced, canyon-dominated Southwest Grand Banks Slope, Canada. Sedimentology 57, 1387-1408. Armitage, D.A., Romans, B.W., Covault, J.A., Graham, S.A., 2009. The influence of mass-transport-deposit surface topography on the evolution of turbidite architecture: the Sierra Contreras, Tres Pasos formation (Cretaceous), southern Chile. Journal of Sedimentary Research 79, 287-301.

Badhani, S., Cattaneo, A., Dennielou, B., Leroux, E., Colin, F., Thomas, Y., Jouet, G., Rabineau, M., Droz, L., 2020. Morphology of retrogressive failures in the Eastern Rhone interfluve during the last glacial maximum (Gulf of Lions, Western Mediterranean). Geomorphology 351, 106894.

Baztan, J., Berné, S., Olivet, J.-L., Rabineau, M., Aslanian, D., Gaudin, M., Réhault, J.-P., Canals, M., 2005. Axial incision: The key to understand submarine canyon evolution (in the western Gulf of Lion). Marine and Petroleum Geology 22, 805-826.

Bornhold, B.D., Prior, D.B., 1989. Sediment blocks on the sea floor in British Columbia fjords. Geo-Marine Letters 9, 135.

Bryn, P., Berg, K., Forsberg, C.F., Solheim, A., Kvalstad, T.J., 2005. Explaining the Storegga slide. Marine and Petroleum Geology 22, 11-19.

Bull, S., Cartwright, J., Huuse, M., 2009. A review of kinematic indicators from mass-transport complexes using 3D seismic data. Marine and Petroleum Geology 26, 1132-1151.

Canals, M., Puig, P., de Madron, X.D., Heussner, S., Palanques, A., Fabres, J., 2006. Flushing submarine canyons. Nature 444, 354-357.

Covault, J.A., Normark, W.R., Romans, B.W., Graham, S.A., 2007. Highstand fans in the California borderland: The overlooked deep-water depositional systems. Geology 35, 783-786.

Dickinson, J.A., Wallace, M.W., Holdgate, G.R., Gallagher, S.J., Thomas, L., 2002. Origin and timing of the Miocene-Pliocene unconformity in southeast Australia. Journal of Sedimentary Research 72, 288-303. Dugan, B., Flemings, P.B., 2000. Overpressure and fluid flow in the New Jersey continental slope: Implications for slope failure and cold seeps. Science 289, 288-291.

Duran, E.R., Phillips, H.E., Furue, R., Spence, P., Bindoff, N.L., 2020. Southern Australia Current System based on a gridded hydrography and a high-resolution model. Progress in Oceanography 181, 102254. Farre, J.A., McGregor, B.A., Ryan, W.B., Robb, J.M., 1983. Breaching the shelfbreak: passage from youthful to mature phase in submarine canyon evolution.

Fenner, P., Kelling, G., Stanley, D.J., 1971. Bottom currents in Wilmington submarine canyon. Nature Physical Science 229, 52-54.

Frey Martinez, J., Cartwright, J., Hall, B., 2005. 3D seismic interpretation of slump complexes: examples from the continental margin of Israel. Basin Research 17, 83-108.

Gibson, G.M., Totterdell, J., White, L.T., Mitchell, C., Stacey, A., Morse, M., Whitaker, A., 2013. Preexisting basement structure and its influence on continental rifting and fracture zone development along Australia's southern rifted margin. Journal of the Geological Society 170, 365-377. 
Godfrey, J., Vaudrey, D., Hahn, S., 1986. Observations of the shelf-edge current south of Australia, winter 1982. Journal of Physical Oceanography 16, 668-679.

Gong, C., Wang, Y., Zhu, W., Li, W., Xu, Q., Zhang, J., 2011. The Central Submarine Canyon in the Qiongdongnan Basin, northwestern South China Sea: architecture, sequence stratigraphy, and depositional processes. Marine and petroleum Geology 28, 1690-1702.

Green, A., Uken, R., 2008. Submarine landsliding and canyon evolution on the northern KwaZulu-Natal continental shelf, South Africa, SW Indian Ocean. Marine Geology 254, 152-170.

Harris, P.T., Whiteway, T., 2011. Global distribution of large submarine canyons: Geomorphic differences between active and passive continental margins. Marine Geology 285, 69-86.

He, Y., Zhong, G., Wang, L., Kuang, Z., 2014. Characteristics and occurrence of submarine canyonassociated landslides in the middle of the northern continental slope, South China Sea. Marine and Petroleum Geology 57, 546-560.

Holford, S.P., Tuitt, A.K., Hillis, R.R., Green, P.F., Stoker, M.S., Duddy, I.R., Sandiford, M., Tassone, D.R., 2014. Cenozoic deformation in the Otway Basin, southern Australian margin: Implications for the origin and nature of post-breakup compression at rifted margins. Basin Research 26, 10-37.

Ito, M., 2013. The role of slump scars in slope channel initiation: a case study from the Miocene Jatiluhur Formation in the Bogor Trough, West Java. Journal of Asian Earth Sciences 73, 68-86.

Jackson, C.A., Johnson, H.D., 2009. Sustained turbidity currents and their interaction with debriterelated topography; Labuan Island, offshore NW Borneo, Malaysia. Sedimentary Geology 219, 77-96. Jobe, Z.R., Lowe, D.R., Uchytil, S.J., 2011. Two fundamentally different types of submarine canyons along the continental margin of Equatorial Guinea. Marine and Petroleum Geology 28, 843-860.

Kneller, B., Dykstra, M., Fairweather, L., Milana, J.P., 2016. Mass-transport and slope accommodation: Implications for turbidite sandstone reservoirs. AAPG Bulletin 100, 213-235.

Krassay, A., Cathro, D., Ryan, D., 2004. A regional tectonostratigraphic framework for the Otway Basin. Leach, A., Wallace, M., 2001. Cenozoic submarine canyon systems in cool water carbonates from the Otway Basin, Victoria, Australia.

Lee, H.J., Locat, J., Desgagnés, P., Parsons, J.D., McAdoo, B.G., Orange, D.L., Puig, P., Wong, F.L., Dartnell, P., Boulanger, E., 2007. Submarine mass movements on continental margins, Continental margin sedimentation: from sediment transport to sequence stratigraphy. Citeseer, pp. 213-274. Li, W., Alves, T.M., Rebesco, M., Sun, J., Li, J., Li, S., Wu, S., 2020. The Baiyun Slide Complex, South China Sea: A modern example of slope instability controlling submarine-channel incision on continental slopes. Marine and Petroleum Geology 114, 104231.

Li, W., Alves, T.M., Urlaub, M., Georgiopoulou, A., Klaucke, I., Wynn, R.B., Gross, F., Meyer, M., Repschläger, J., Berndt, C., 2017. Morphology, age and sediment dynamics of the upper headwall of the Sahara Slide Complex, Northwest Africa: Evidence for a large Late Holocene failure. Marine Geology 393, 109-123.

Locat, A., Leroueil, S., Bernander, S., Demers, D., Jostad, H.P., Ouehb, L., 2011. Progressive failures in eastern Canadian and Scandinavian sensitive clays. Canadian Geotechnical Journal 48, 1696-1712.

Loncke, L., Gaullier, V., Droz, L., Ducassou, E., Migeon, S., Mascle, J., 2009. Multi-scale slope instabilities along the Nile deep-sea fan, Egyptian margin: A general overview. Marine and Petroleum Geology 26, 633-646.

McAdoo, B., Pratson, L., Orange, D., 2000. Submarine landslide geomorphology, US continental slope. Marine Geology 169, 103-136.

McGowran, B., Holdgate, G., Li, Q., Gallagher, S., 2004. Cenozoic stratigraphic succession in southeastern 
Australia. Australian Journal of Earth Sciences 51, 459-496.

Micallef, A., Mountjoy, J.J., Canals, M., Lastras, G., 2012. Deep-seated bedrock landslides and submarine canyon evolution in an active tectonic margin: Cook Strait, New Zealand, Submarine mass movements and their consequences. Springer, pp. 201-212.

Miramontes, E., Eggenhuisen, J.T., Jacinto, R.S., Poneti, G., Pohl, F., Normandeau, A., Campbell, D.C., Hernández-Molina, F.J., 2020. Channel-levee evolution in combined contour current-turbidity current flows from flume-tank experiments. Geology 48, 353-357.

Moscardelli, L., Wood, L., 2008. New classification system for mass transport complexes in offshore Trinidad. Basin Research 20, 73-98.

Moscardelli, L., Wood, L., 2016. Morphometry of mass-transport deposits as a predictive tool. Bulletin 128, 47-80.

Moscardelli, L., Wood, L., Mann, P., 2006. Mass-transport complexes and associated processes in the offshore area of Trinidad and Venezuela. AAPG bulletin 90, 1059-1088.

Normandeau, A., Lajeunesse, P., St-Onge, G., 2015. Submarine canyons and channels in the Lower St. Lawrence Estuary (Eastern Canada): Morphology, classification and recent sediment dynamics. Geomorphology 241, 1-18.

Normandeau, A., Lajeunesse, P., St-Onge, G., Bourgault, D., Drouin, S.S.-O., Senneville, S., Belanger, S., 2014. Morphodynamics in sediment-starved inner-shelf submarine canyons (Lower St. Lawrence Estuary, Eastern Canada). Marine Geology 357, 243-255.

Nugraha, H.D., Jackson, C.A.-L., Johnson, H.D., Hodgson, D.M., Clare, M., 2019. How erosive are submarine landslides?

Nugraha, H.D., Jackson, C.A.L., Johnson, H.D., Hodgson, D.M., Reeve, M.T., 2018. Tectonic and oceanographic process interactions archived in Late Cretaceous to Present deep-marine stratigraphy on the Exmouth Plateau, offshore NW Australia. Basin Research.

Obelcz, J., Brothers, D., Chaytor, J., ten Brink, U., Ross, S.W., Brooke, S., 2014. Geomorphic characterization of four shelf-sourced submarine canyons along the US Mid-Atlantic continental margin. Deep Sea Research Part II: Topical Studies in Oceanography 104, 106-119.

Ortiz-Karpf, A., Hodgson, D., McCaffrey, W., 2015. The role of mass-transport complexes in controlling channel avulsion and the subsequent sediment dispersal patterns on an active margin: the Magdalena Fan, offshore Colombia. Marine and Petroleum Geology 64, 58-75.

Paull, C., Caress, D., Lundsten, E., Gwiazda, R., Anderson, K., McGann, M., Conrad, J., Edwards, B., Sumner, E., 2013. Anatomy of the La Jolla submarine canyon system; offshore Southern California. Marine Geology 335, 16-34.

Perincek, D., Cockshell, C., 1995. The Otway basin: early Cretaceous rifting to Neogene inversion. The APPEA Journal 35, 451-466.

Popescu, I., Lericolais, G., Panin, N., Normand, A., Dinu, C., Le Drezen, E., 2004. The Danube submarine canyon (Black Sea): morphology and sedimentary processes. Marine Geology 206, 249-265.

Posamentier, H., Erskine, R., Mitchum, R., 1991. Models for submarine-fan deposition within a sequence-stratigraphic framework, Seismic facies and sedimentary processes of submarine fans and turbidite systems. Springer, pp. 127-136.

Posamentier, H.W., Martinsen, O.J., 2011. The character and genesis of submarine mass-transport deposits: insights from outcrop and 3D seismic data. Mass-transport deposits in deepwater settings: Society for Sedimentary Geology (SEPM) Special Publication 96, 7-38.

Pratson, L.F., Coakley, B.J., 1996. A model for the headward erosion of submarine canyons induced by 
downslope-eroding sediment flows. Geological Society of America Bulletin 108, 225-234.

Pratson, L.F., Ryan, W.B., 1994. Pliocene to recent infilling and subsidence of intraslope basins offshore Louisiana. AAPG bulletin 78, 1483-1506.

Puga-Bernabéu, Á., Webster, J.M., Beaman, R.J., Guilbaud, V., 2011. Morphology and controls on the evolution of a mixed carbonate-siliciclastic submarine canyon system, Great Barrier Reef margin, northeastern Australia. Marine Geology 289, 100-116.

Qin, Y., Alves, T.M., Constantine, J., Gamboa, D., 2017. The role of mass wasting in the progressive development of submarine channels (Espirito Santo Basin, SE Brazil). Journal of Sedimentary Research 87, 500-516.

Ridgway, K., 2007. Seasonal circulation around Tasmania: an interface between eastern and western boundary dynamics. Journal of Geophysical Research: Oceans 112.

Sawyer, D.E., 2007. Lateral Variations in Core, Log, and Seismic Attributes of a Mass Transport Complex in the Ursa Region, IODP Expedition 308, Northern Gulf of Mexico.

Sawyer, D.E., Flemings, P.B., Dugan, B., Germaine, J.T., 2009. Retrogressive failures recorded in mass transport deposits in the Ursa Basin, Northern Gulf of Mexico. Journal of Geophysical Research: Solid Earth 114.

Sequeiros, O.E., Pittaluga, M.B., Frascati, A., Pirmez, C., Masson, D.G., Weaver, P., Crosby, A.R., Lazzaro, G., Botter, G., Rimmer, J.G., 2019. How typhoons trigger turbidity currents in submarine canyons. Scientific reports 9, 1-15.

Shepard, F.P., 1972. Submarine canyons. Earth-Science Reviews 8, 1-12.

Shepard, F.P., Dill, R.F., Dill, R.F., 1966. Submarine canyons and other sea valleys. Rand McNally.

Shepard, F.P., Marshall, N.F., McLoughlin, P.A., 1974. "Internal Waves" Advancing along Submarine Canyons. Science 183, 195-198.

Shipp, R.C., 2004. Physical Characteristics and Impact of Mass Transport Complexes on Deepwater Jetted Conductors and Suction Anchor Piles.

Stow, D.A., Mayall, M., 2000. Deep-water sedimentary systems: new models for the 21st century. Marine and Petroleum Geology 17, 125-135.

Su, M., Lin, Z., Wang, C., Kuang, Z., Liang, J., Chen, H., Liu, S., Zhang, B., Luo, K., Huang, S., 2020. Geomorphologic and infilling characteristics of the slope-confined submarine canyons in the Pearl River Mouth Basin, northern South China Sea. Marine Geology 424, 106166.

Tassone, D., Holford, S., Tingay, M., Tuitt, A., Stoker, M., Hillis, R., 2011. Overpressures in the central Otway Basin: the result of rapid Pliocene-Recent sedimentation? The APPEA Journal 51, 439-458.

Totterdell, J., Bradshaw, M., Owen, K., Hashimoto, T., Hall, L., 2014. Petroleum geology inventory of Australia's offshore frontier basins. Geoscience Australia.

Twichell, D.C., Roberts, D.G., 1982. Morphology, distribution, and development of submarine canyons on the United States Atlantic continental slope between Hudson arid Baltimore Canyons. Geology 10, 408-412.

Urgeles, R., Camerlenghi, A., 2013. Submarine landslides of the Mediterranean Sea: Trigger mechanisms, dynamics, and frequency-magnitude distribution. Journal of Geophysical Research: Earth Surface 118, 2600-2618.

Vail, P., 1977. Seismic stratigraphy and global changes of sea level. Bull. Am. Assoc. Petrol. Geol., Mem. 26, 49-212.

Warratz, G., Schwenk, T., Voigt, I., Bozzano, G., Henrich, R., Violante, R., Lantzsch, H., 2019. Interaction of a deep-sea current with a blind submarine canyon (Mar del Plata Canyon, Argentina). Marine Geology 
417, 106002.

647 Watson, S.J., Mountjoy, J.J., Crutchley, G.J., 2020. Tectonic and geomorphic controls on the distribution 648 of submarine landslides across active and passive margins, eastern New Zealand. Geological Society, 649 London, Special Publications 500, 477-494.

650 Weimer, P., Slatt, R.M., 2004. Petroleum systems of deepwater settings. Society of Exploration 651 Geophysicists and European Association of ....

652 Willcox, J., Stagg, H., 1990. Australia's southern margin: a product of oblique extension. Tectonophysics $653173,269-281$.

654 Williams, S.C., 2016. News Feature: Skimming the surface of underwater landslides. Proceedings of the 655 National Academy of Sciences 113, 1675-1678.

656 Wu, N., Jackson, C.A.L., Johnson, H.D., Hodgson, D.M., Clare, M.A., Nugraha, H.D., Li, W., 2021. The 657 formation and implications of giant blocks and fluid escape structures in submarine lateral spreads. 658 Basin Research.

659 Xu, J., Swarzenski, P.W., Noble, M., Li, A.-C., 2010. Event-driven sediment flux in Hueneme and Mugu 660 submarine canyons, southern California. Marine Geology 269, 74-88.

661 Zhong, G., Cartigny, M.J., Kuang, Z., Wang, L., 2015. Cyclic steps along the South Taiwan Shoal and West 662 Penghu submarine canyons on the northeastern continental slope of the South China Sea. Bulletin 127, 663 804-824. 


\section{Figures}

Figure 1
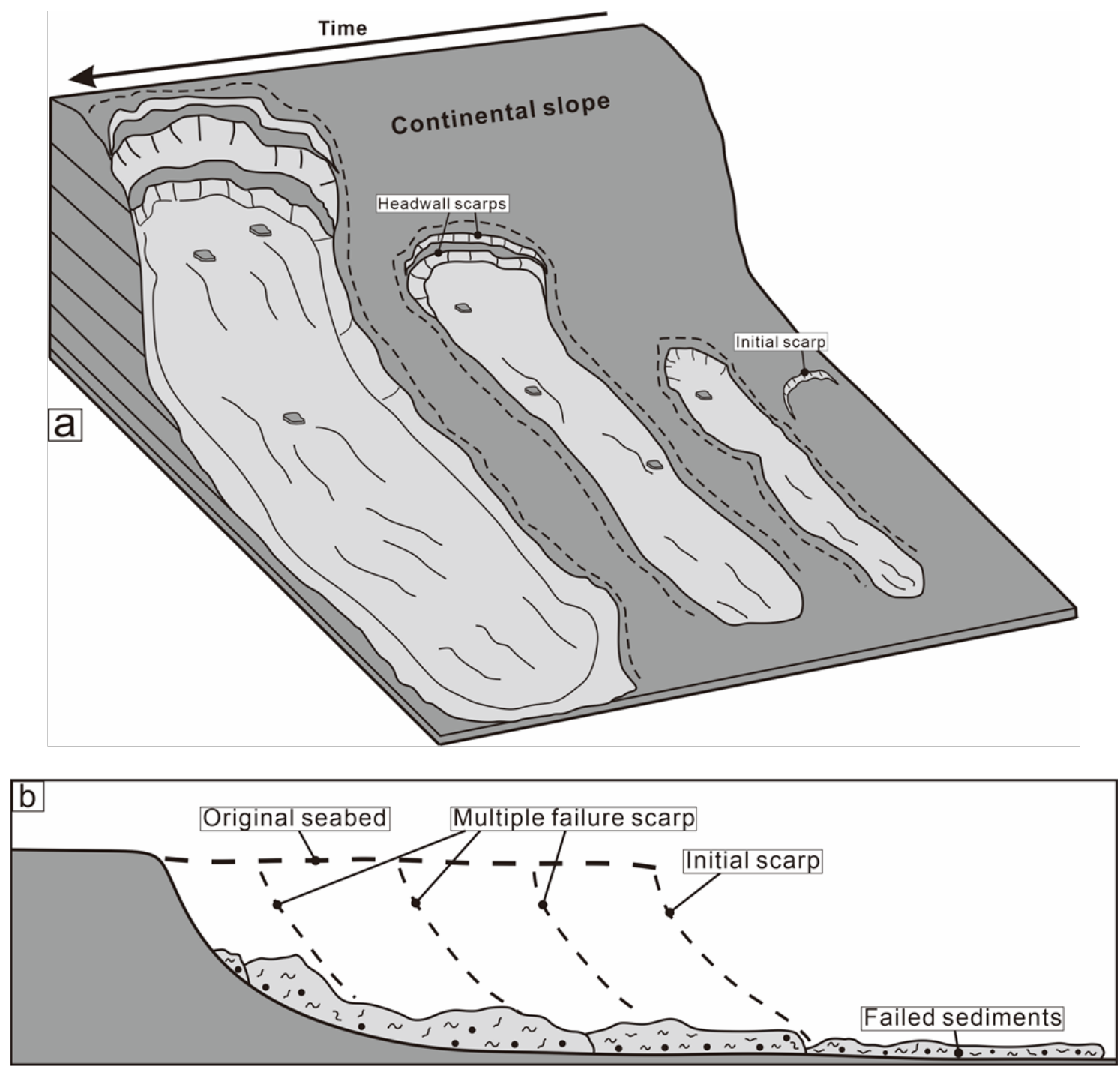


\section{Figure 2}
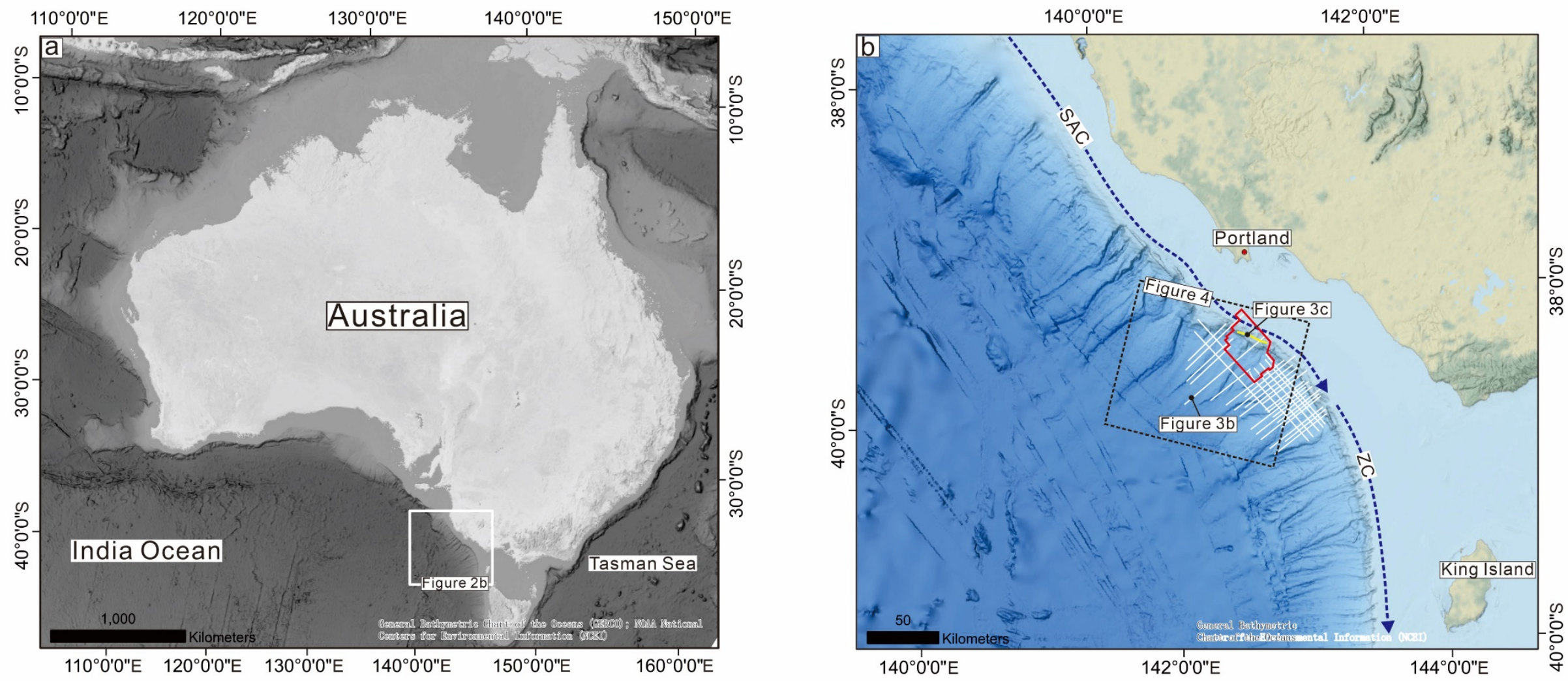
Figure 3
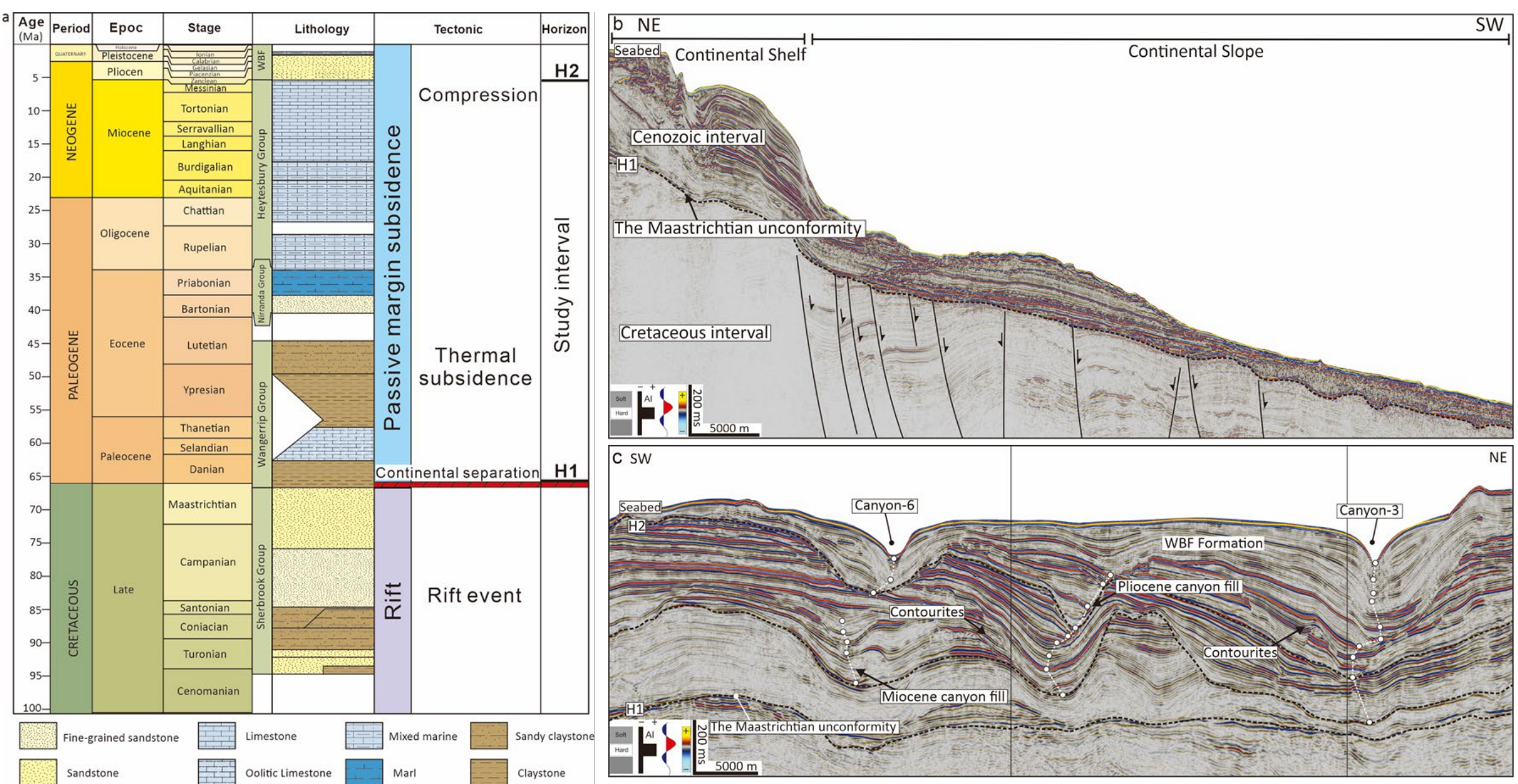
Figure 4
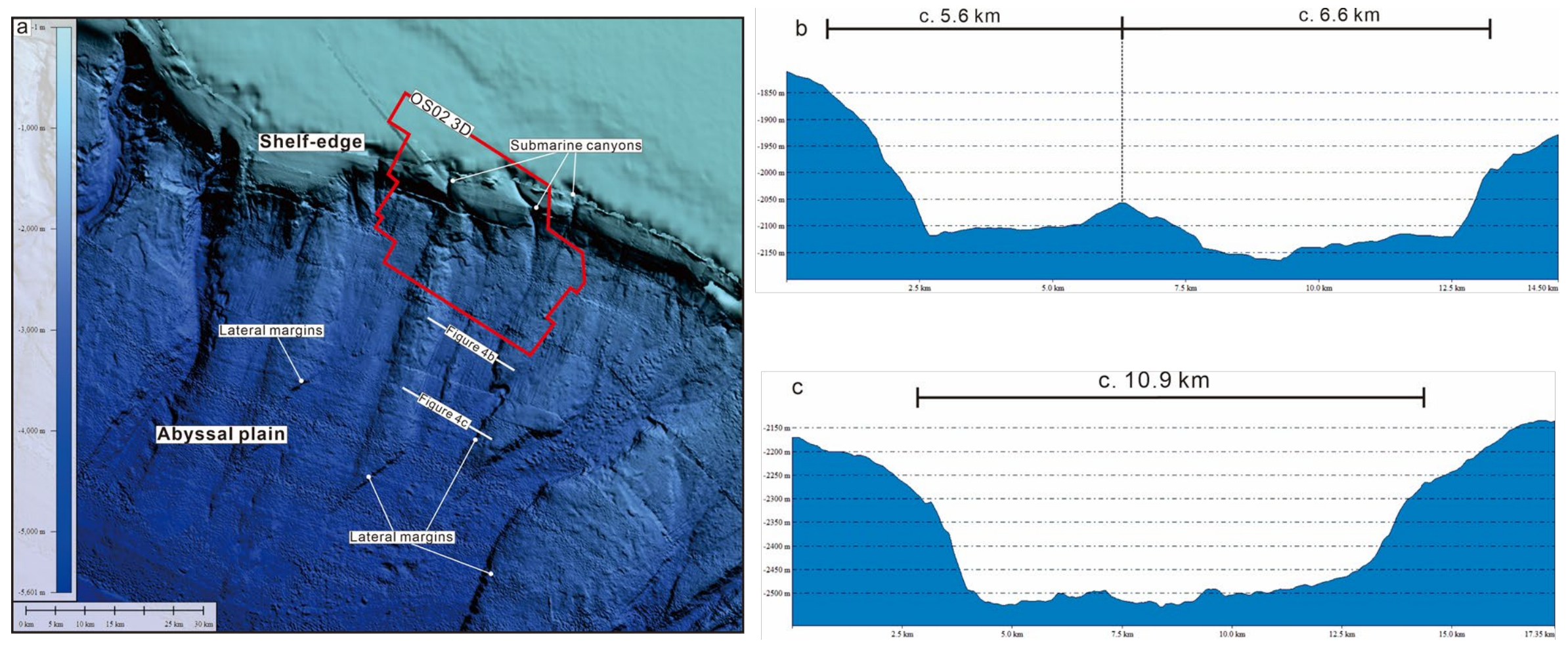
Figure 5

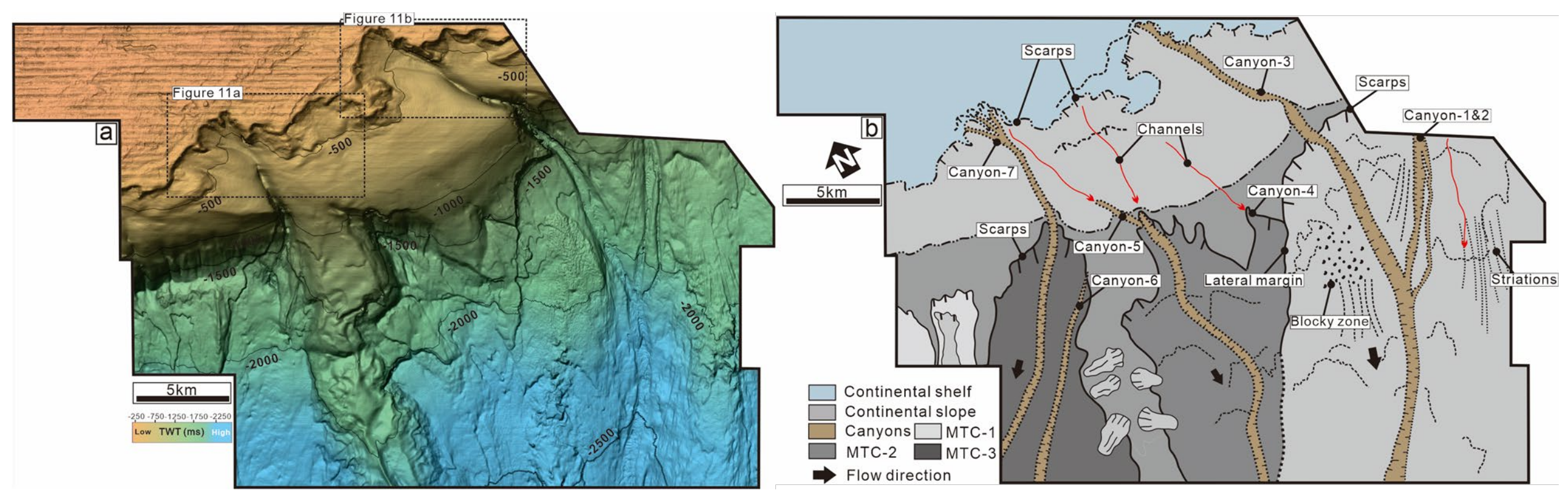


Figure 6

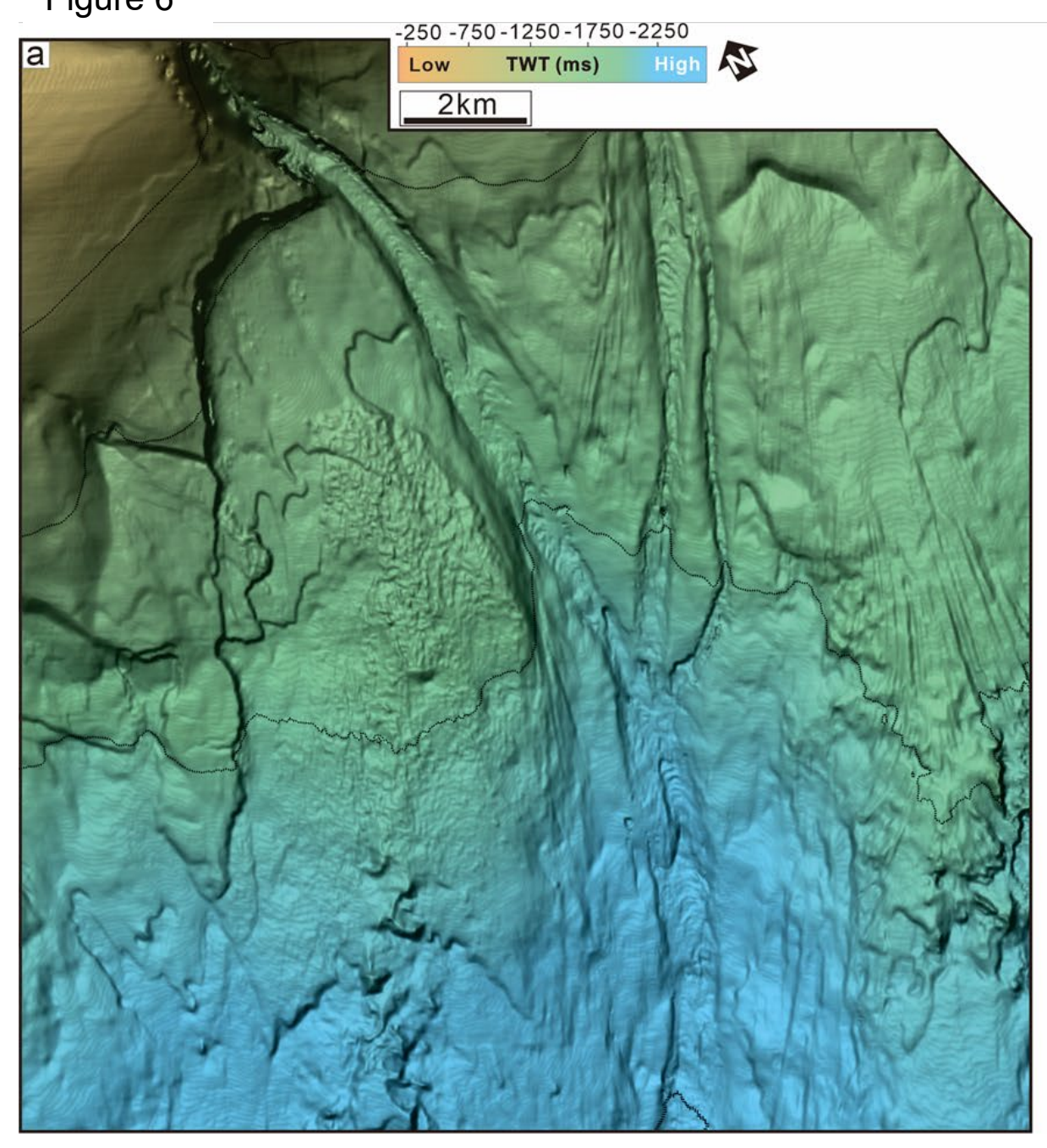

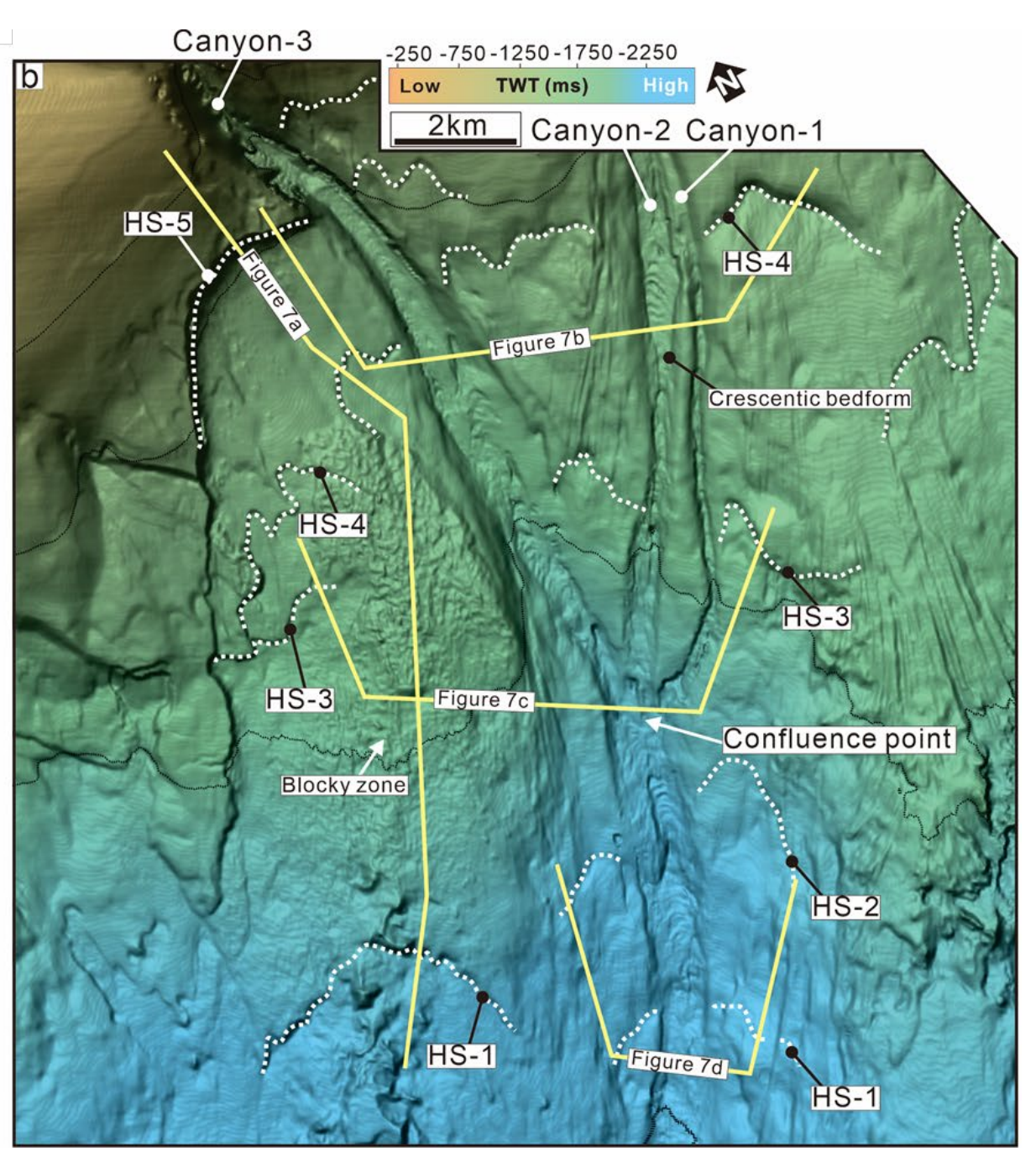


Figure 7
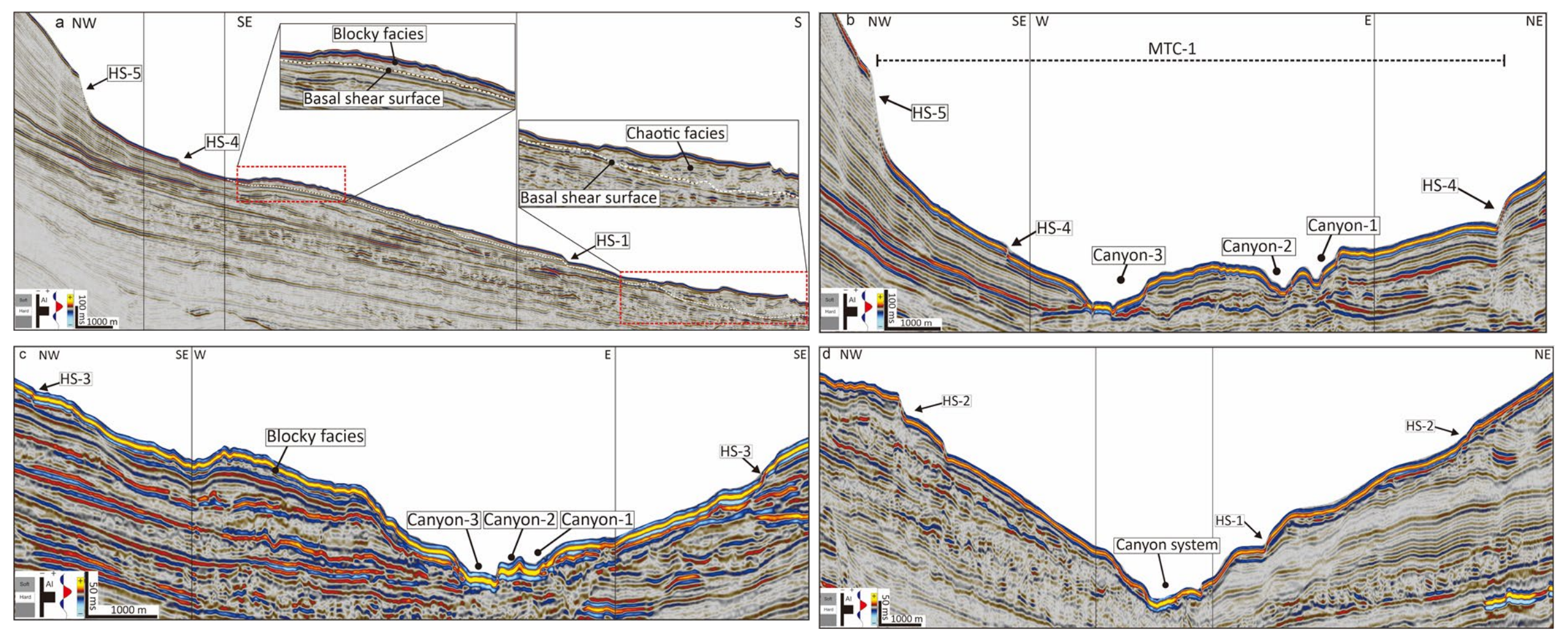

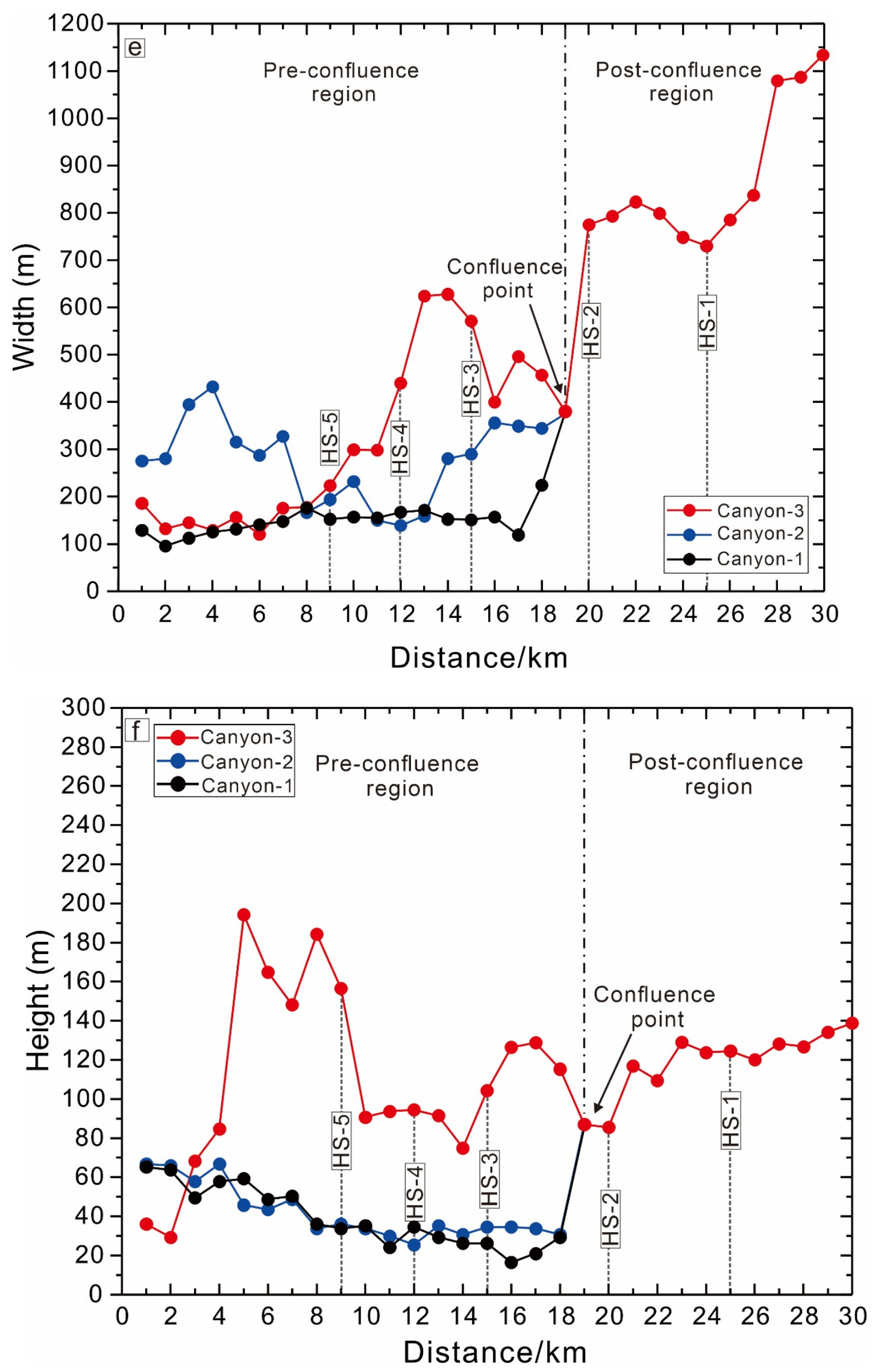
Figure 8

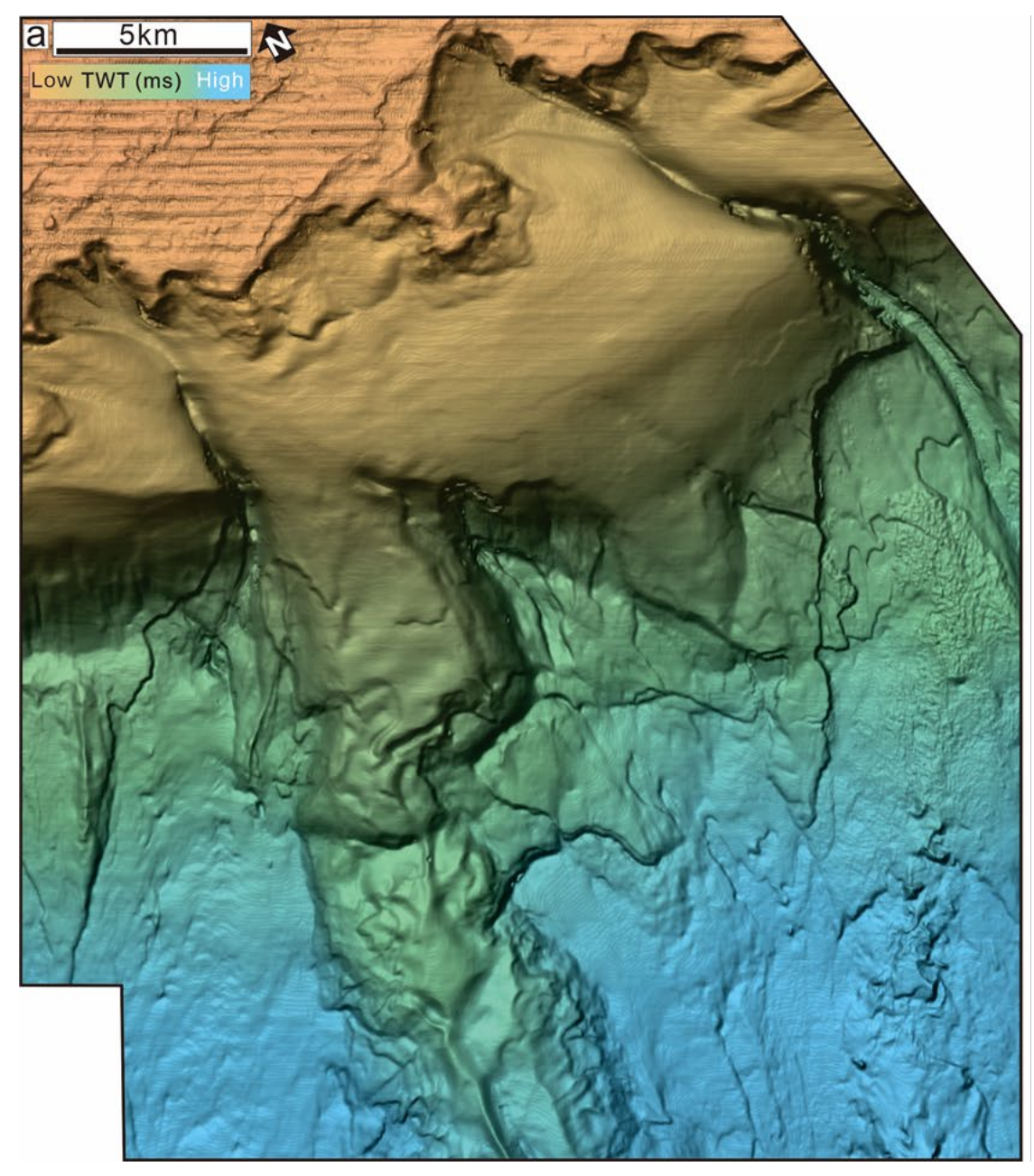

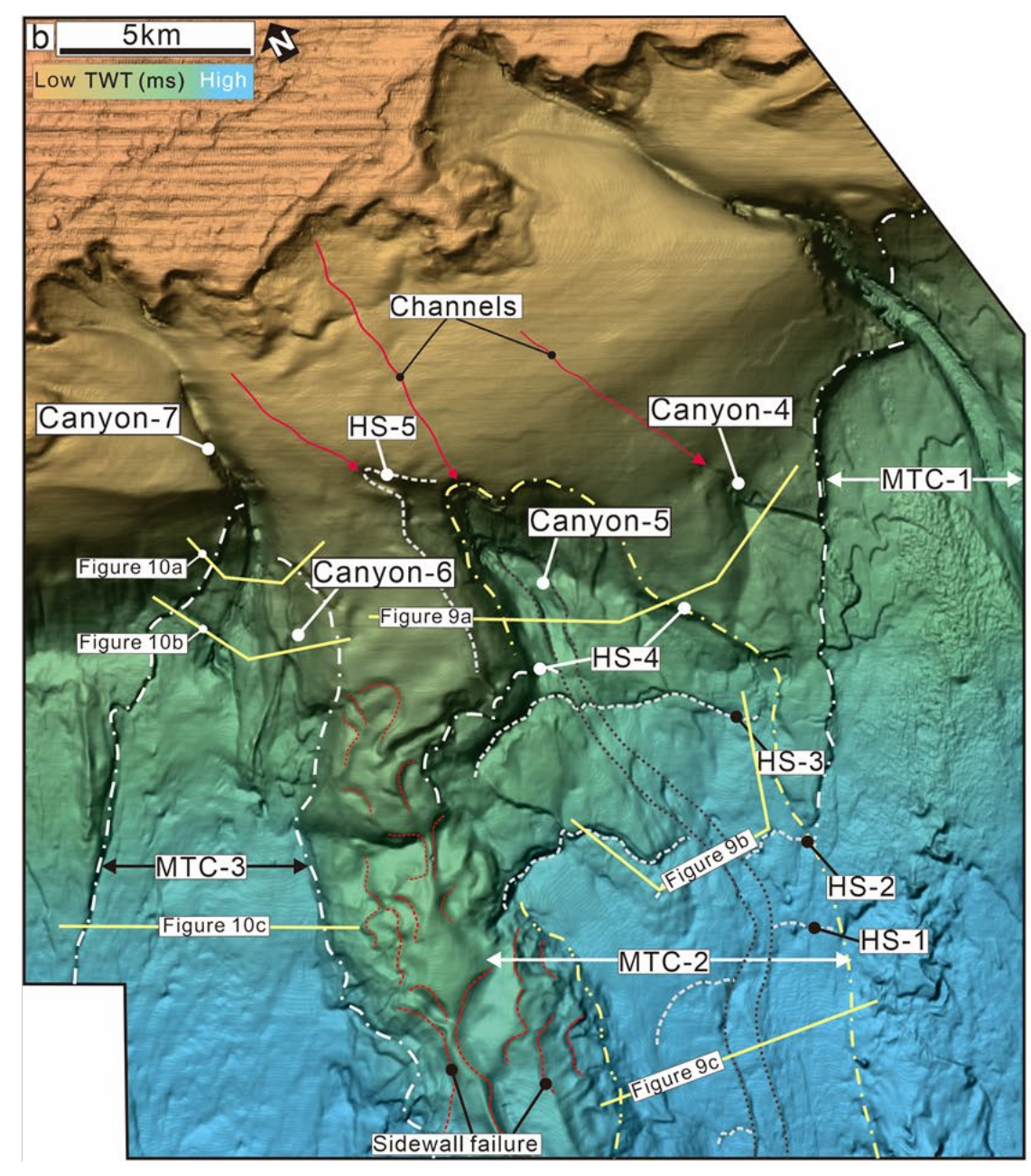


Figure 9
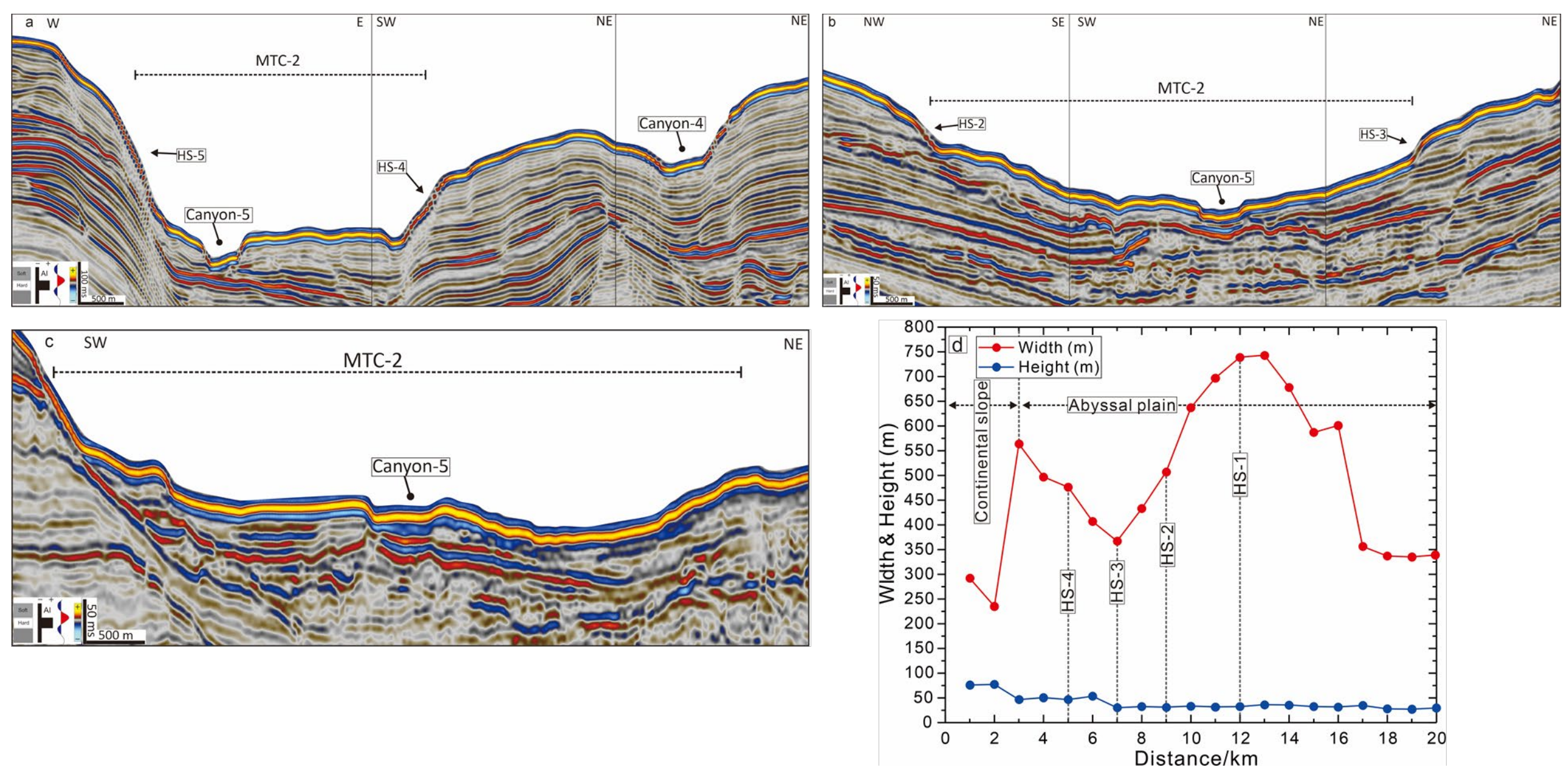
Figure 10
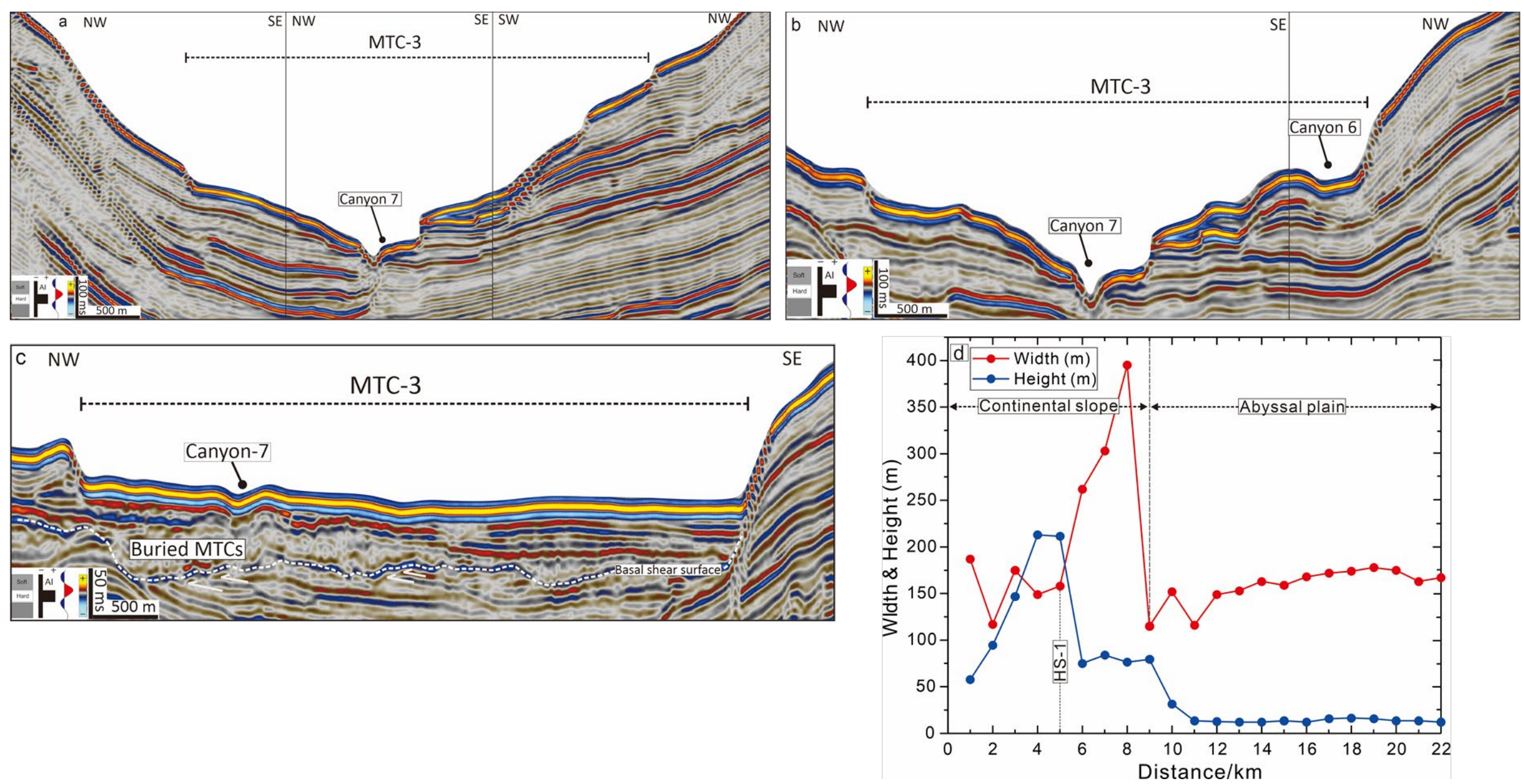
Figure 11
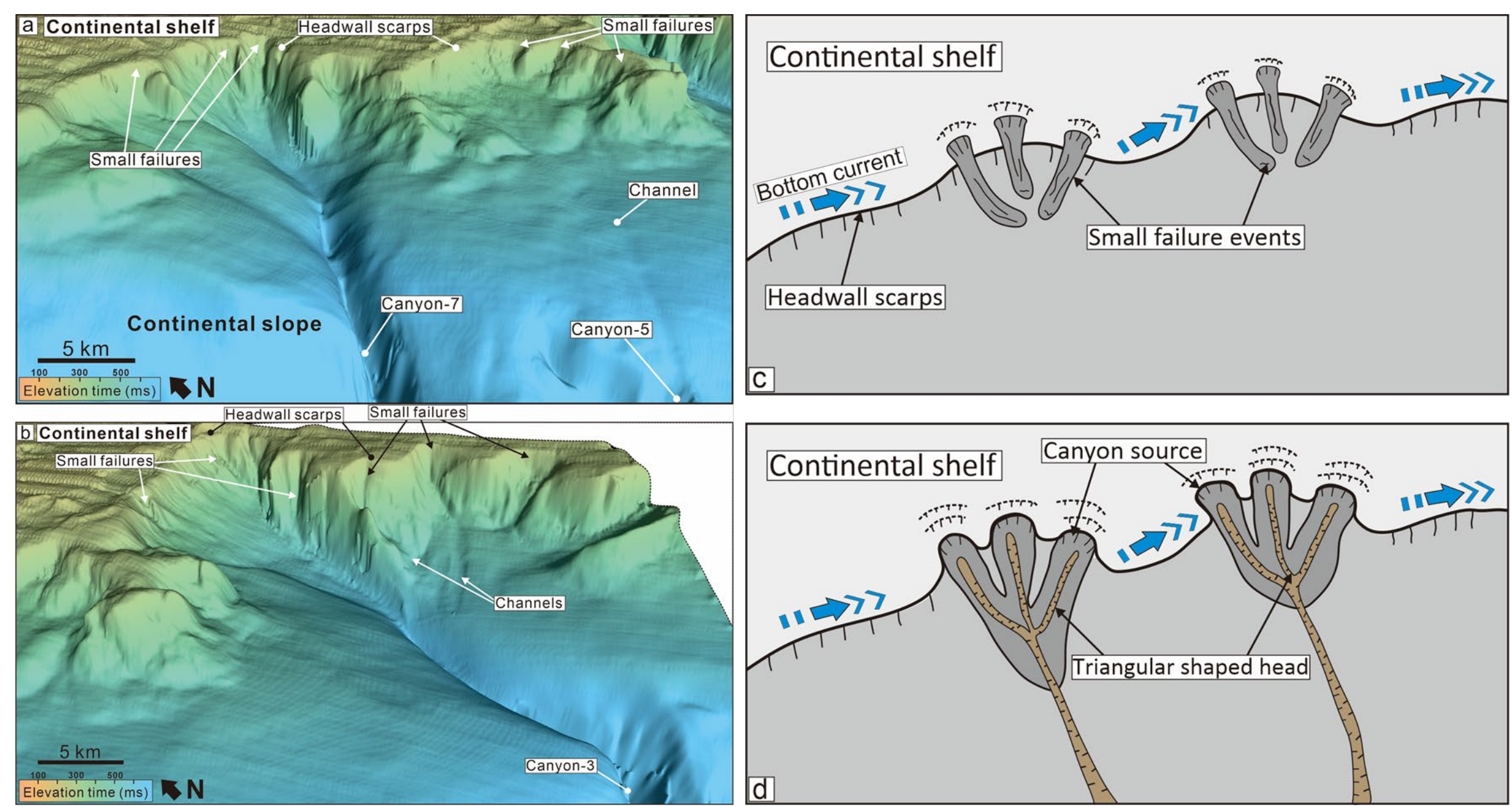
Figure 12
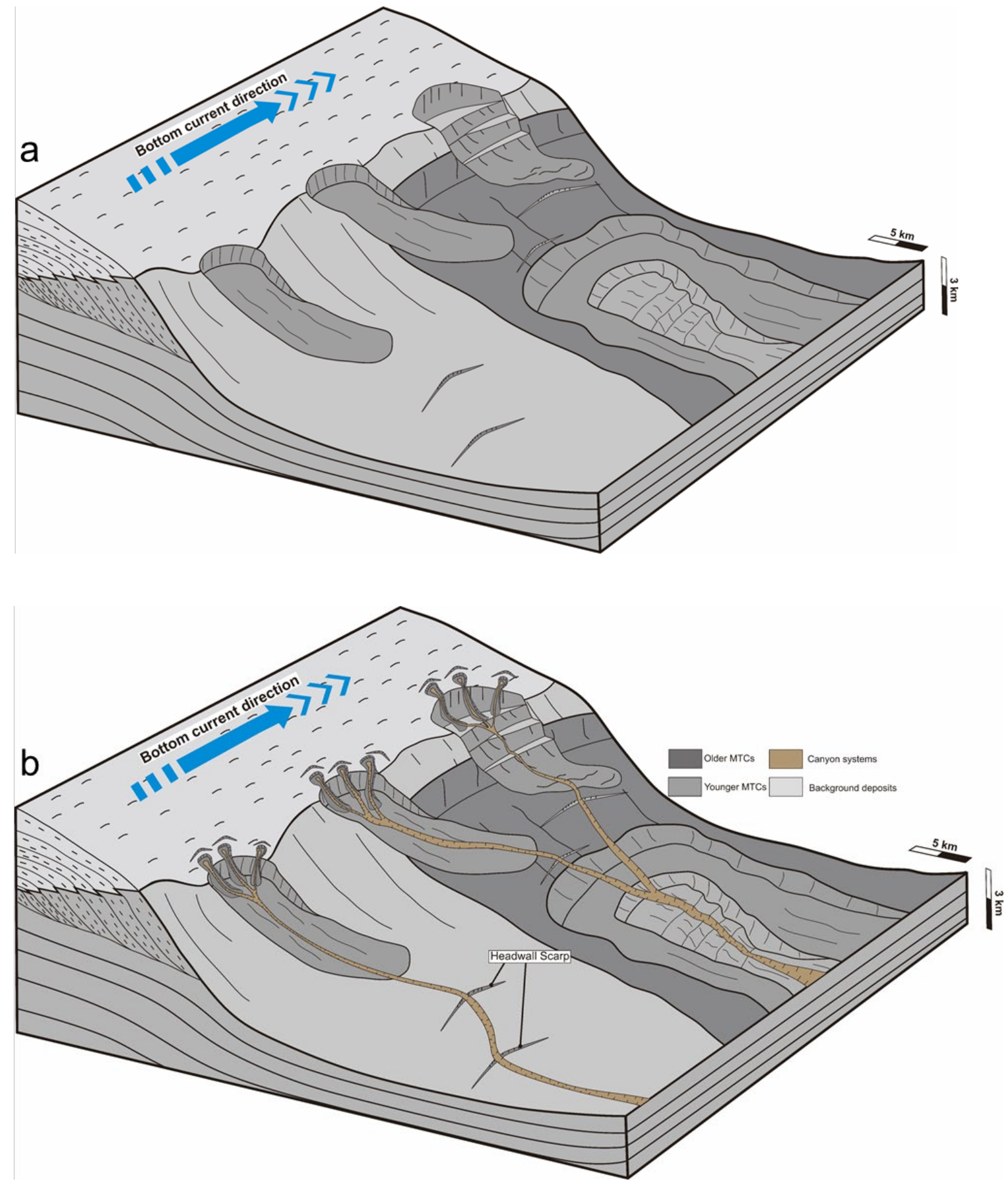